\title{
Applications of hemp in textiles, paper industry, insulation and building materials, horticulture, animal nutrition, food and beverages, nutraceuticals, cosmetics and hygiene, medicine, agrochemistry, energy production and environment: a review
}

\author{
Grégorio Crini $^{1}$ - Eric Lichtfouse ${ }^{2} \quad \cdot$ Gilles Chanet $^{3} \cdot$ Nadia Morin-Crini $^{1}$
}

\begin{abstract}
The hemp plant Cannabis sativa Linn, referring to industrial hemp, is a high-yielding annual industrial crop grown providing fibers from hemp stalk and oil from hemp seeds. Although hemp is a niche crop, hemp production is currently undergoing a renaissance. More than 30 countries grow hemp, with China being the largest hemp producing and exporting country. Europe and Canada are also important actors in the global hemp market. Traditionally, hemp as a fiber plant has been used for the production of apparels, fabrics, papers, cordages and building materials. The hurds, as waste by-product of fiber production, were used for bedding of animals, the seeds for human nutrition, e.g., as flour, and the oil for a wide range of purposes, from cooking to cosmetics. Hemp has also been an important crop throughout human history for medicine. Other more recent applications include materials for insulation and furniture, automotive composites for interior applications and motor vehicle parts, bioplastics, jewelry and fashion sectors, animal feed, animal bedding, and energy and fuel production. Foods containing hemp seed and oil are currently marketed worldwide for both animal and human nutrition. They also find applications in beverages and in neutraceutical products. Hemp oil is also used for cosmetics and personal care items, paints, printing inks, detergents and solvents. It is estimated that the global market for hemp consists of more than 25,000 products. Currently, the construction and insulation sector, paper and textile industries, and food and nutrition domains are the main markets while the cosmetics and automotive sector are growing markets. Innovative applications, e.g., in the medical and therapeutic domains, cosmeceuticals, phytoremediation, acoustic domain, wastewater treatment, biofuels, biopesticides and biotechnology, open new challenges. Hemp is also the object of numerous fundamental studies. This review presents and discusses the traditional and new uses of industrial hemp.
\end{abstract}

Keywords Hemp applications · Textiles · Paper · Building materials · Food · Beverages · Cosmetics · Biocomposites · Energy production $\cdot$ Biofuel $\cdot$ Environmental uses

Grégorio Crini

gregorio.crini@univ-fcomte.fr

Eric Lichtfouse

eric.lichtfouse@gmail.com

Gilles Chanet

gilles.chanet@interval.coop

Nadia Morin-Crini

nadia.crini@univ-fcomte.fr

1 Laboratoire Chrono-Environnement, UMR 6249, UFR Sciences et Techniques, Université Bourgogne FrancheComté, 16 Route de Gray, 25000 Besançon, France

2 CNRS, IRD, INRA, Coll France, CEREGE, Aix Marseille Univ, Aix-en-Provence, France

3 Eurochanve, 7 Route de Dijon, 70100 Arc-les-Gray, France

\section{Introduction}

Hemp is a dicotyledonous plant from the order of Rosales, from the family of Cannabaceae, genus Cannabis, like marijuana (Bouloc 2013). Hemp originated from Asia and is considered one of the oldest domesticated crops known to man (De Candolle 1883; Vavilov 1992; Lu and Clarke 1995; Amaducci and Gusovious 2010; Allegret 2013).

Hemp-based products such as bits of hemp fabric have been discovered in tombs dating back to 8000 B.C. (Lu and Clarke 1995; Bouloc 2013). Hemp was also cultivated 4500 years ago in China for fiber, seeds and oil production for multiple applications, e.g., cords imprinted on ancient 
pottery shards containing hemp residues and piece of paper made from hemp have been discovered (Vavilov 1992; Roulac 1997; Ranalli 1999; Bouloc 2013). According to ancient Chinese writings, extracts of hemp were also used to treat a wide range of diseases. In Ancient Egypt, the pharaohs also used hemp, e.g., hemp was found in cloth unearthed from the tomb of Pharaoh Alchanaten dating back to 1200 B.C.

In the $600 \mathrm{~s}$, Germans and Vikings made paper, sails and rope from hemp. The Guttenberg Bible was printed on hemp paper in 1456 (Lu and Clarke 1995). In sixteenth to eighteenth century, hemp was a major fiber crop in Europe, Russia and North America (Vavilov 1992; Lu and Clarke 1995; Gibson 2006; Bouloc 2013).

President George Washington grew hemp (Fike 2016), and Americans were legally bound to grow hemp during the Colonial Era and Early Republic (source: Hemp Industries Association). In Colonial days, farmers indeed grew hemp and processed it to make paper, braid ropes, sew clothing, and manufacture canvas sacks. The first American flag was made from it, and the Declaration of Independence drafted on hemp paper in 1776. Pionners used hemp covered wagons (Fike 2016).

For thousands of years, hemp fibers were used for clothing and shoes, cordages, carpets and tarps, maritime ropes, sails and nets, and paper production, the hurds for bedding of animals and as straw for agricultural purposes and other uses, e.g., as waste to be burned and more recently as fuel to power farm equipment, the seeds as nutrition, and the oils for a wide range of purposes, from cooking to personal care. The leaves were also used for mulch, composting and animal bedding (De Candolle 1883; Vavilov 1992; Roulac 1997; Ranalli 1999; Ranalli and Venturi 2004; Amaducci 2005; Gibson 2006; Milanovic et al. 2012; Allegret 2013; Bouloc 2013).

In the middle of 19th century, hemp cultivation decreased with the disappearance of the sailing navy and competition from other natural fibers such as cotton and jute for textile applications, and later due to intensive development of synthetic fibers (Small and Marcus 2002; Ranalli and Venturi 2004; Milanovic et al. 2012). In the 1930s, cultivation was forbidden in most Western countries and in North America due to the fact that both hemp and marijuana come from the same genus and species plant, and this introduced a lot of confusion and social, political and moral controversies (Amaducci 2005; Holler et al. 2008; Bouloc 2013; Sawler et al. 2015; Cherney and Small 2016; Chandra et al. 2017; Das et al. 2017; Johnson 2018).

Indeed, hemp, i.e., plant species Cannabis sativa L., became a controversial crop due to its genetic closeness to THC-producing plants. THC, delta-9-tetrahydrocannabinol, is the chemical most responsible for the psychoactive properties in marijuana. THC is a psychoactive ingredient present in all hemp varieties to some extent. Marijuana, so-called medical cannabis, contains about $10-30 \%$ of THC, while hemp refers to the non-psychoactive varieties of Cannabis sativa L. (Bouloc 2013; Sawler et al. 2015; Pacaphol and Aht-Ong 2017; Żuk-Gołaszewska and Gołaszewski 2018). Hemp, referred to industrial hemp, has less than 0.2-0.3\% THC but contains high levels of cannabidiol (CBD). However, industrial hemp is often incorrectly associated with hemp for narcotics.

Schultes wrote: "Hemp is a green, very abundant and ubiquitous plant, economically valuable, a versatile and multi-purpose product, possibly dangerous and certainly in many ways mysterious" (Schultes 1970). This definition is pertinent in describing the valuable but contradictory nature of this industrial crop.

The 1990s marked the renewal of hemp cultivation from an agricultural, industrial and scientific point of view throughout the world (Bócsa and Karus 1998; Small and Marcus 2002; Karus and Vogt 2004; Ranalli and Venturi 2004; Sponner et al. 2005; Kozlowski et al. 2005; Figueiredo et al. 2010; Thomas et al. 2011; Fike 2016). Indeed, growing interests in the commercial cultivation of hemp and other "forgotten fibers" in Europe and North America have emerged since the 1990s, mainly due to the increasing consideration of natural resources, energy conservation, and biomass conversion to bioproducts and biofuels (Roulac 1997; Gibson 2006; Kostić et al. 2003; Ranalli and Venturi 2004; Sponner et al. 2005; Kozlowski et al. 2005; Figueiredo et al. 2010; Thomas et al. 2011; Faruk et al. 2012).

Since 1992, France, The Netherlands, England, Spain and Germany have passed legislation allowing for the commercial cultivation of low-THC hemp. Two years later, Canada also proposed regulations for hemp cultivation, about 60 years after its prohibition.

Hemp is then considered as a valuable crop with particular agronomic characteristics that provided raw materials, i.e., fibers and oil, suitable for multiple potential applications. It quickly found concrete industrial applications, e.g., hempcrete was becoming a viable alternative to traditional building materials, particularly for insulation, panels and roofs (Small and Marcus 2002; Amaducci 2005). Using environmental-friendly and sustainable hemp-based materials for building insulation and construction was a pertinent approach to address reduction in carbon dioxide emission.

To build cars, processing processes allowed hemp fibers to be incorporated into biocomposites that are lighter than steel and much stronger. Another valuable field was the manufacture of biodegradable and non-toxic plastics based on hemp, referred to as bioplastics. Indeed, industrial hemp has become an attractive biomass for bioplastic production although this material is typically resistant to enzymatic hydrolysis and direct fermentation by microorganism, due to the complex interactions of cellulose, hemicellulose lignin, and pectin. 
The hemp oil was also used for food uses and for applications in cosmetics and personal care. All these areas continue to be exploited today, and there are also other very active and innovative industrial markets for hempbased materials and products (Fig. 1).

Currently, more than 30 nations grow industrial hemp as an agricultural commodity with high potential (Food and Agriculture Organization of the United Nations, www. faostat.fao.org). This plant is being mainly cultivated in China, the largest supplier in the world, in North Korea, Chile, Russia, Canada and Europe (Bouloc 2013; Salentijn et al. 2015; Żuk-Gołaszewska and Gołaszewski 2018). France is the top European producer of hemp with an area of cultivation around 12,000 ha (Morin-Crini et al. 2018, 2019). Hemp cultivation and hemp industry are also important in Lithuania, Germany, Italy, Poland, The Netherlands, Romania, Estonia, Hungary, Spain, and England (Żuk-Gołaszewska and Gołaszewski 2018).

Its production is, however, strictly controlled under existing National and European laws. In most European countries, the current upper legal limit for cultivation of industrial hemp for fiber and seeds production is $0.2 \%$ THC on dry basis (Russo and Reggiani 2013; Salentijn et al. 2015; Frassinetti et al. 2018). This restriction has reduced the number of varieties available for its cultivation. Hemp is currently subsidized by the European Union for non-food agriculture and research purposes, and a considerable initiative for its further development in Europe is underway.
Hemp is considered as a low-cost, ecological, sustainable and multi-use plant (Faruk et al. 2012; Shahzad 2012; Bouloc 2013; Stevulova et al. 2014; Bono et al. 2015; Johnson 2018; Karche and Singh 2019; Manaia et al. 2019). An important advantage is the fact that the entire plant, i.e., seeds and plant stem, is recoverable (Fig. 2). Another advantage is hemp versatility, being useable in various forms, e.g., fibers, felts, powders, shives, and seed products including seeds themselves, oil and oil cake (Roulac 1997; Johnson 1999; Ranalli and Venturi 2004; Sadrmanesh and Chen 2019). All these products can be used for a myriad of applications as reported in Fig. 1. The global market for industrial hemp has more than 25,000 products in nine main submarkets: textiles, agriculture, automotive, food and beverages, paper, furniture, construction, recycling, and personal care. Johnson (2018) recently reported that the sales of hempbased product in the USA alone is about $\$ 600$ million dollars in 2017.

From a scientific point of view, hemp is also the object of numerous fundamental studies and a great deal of research is being conducted around the world. An indication of the widespread exploitation and constantly growing importance of this plant is the total of over 3800 scientific articles published between in the last 5 years (ISI Web of Science database). It is interesting to note that a majority of these investigations have been done in China, Korea, North America, Russia and Europe.

This review presents and discusses the traditional and new uses of industrial hemp, based on a large number of

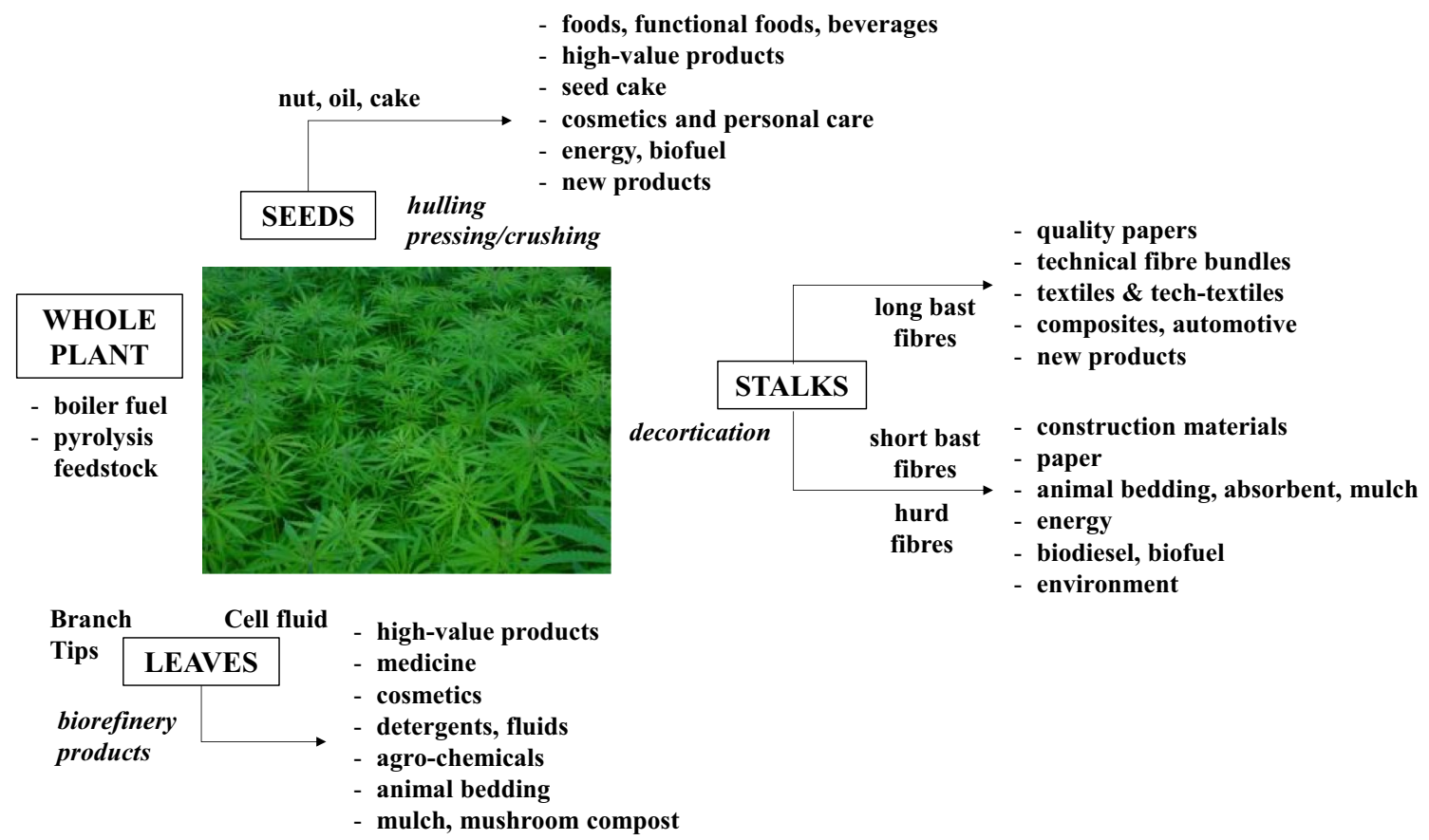

Fig. 1 Modern applications of hemp 


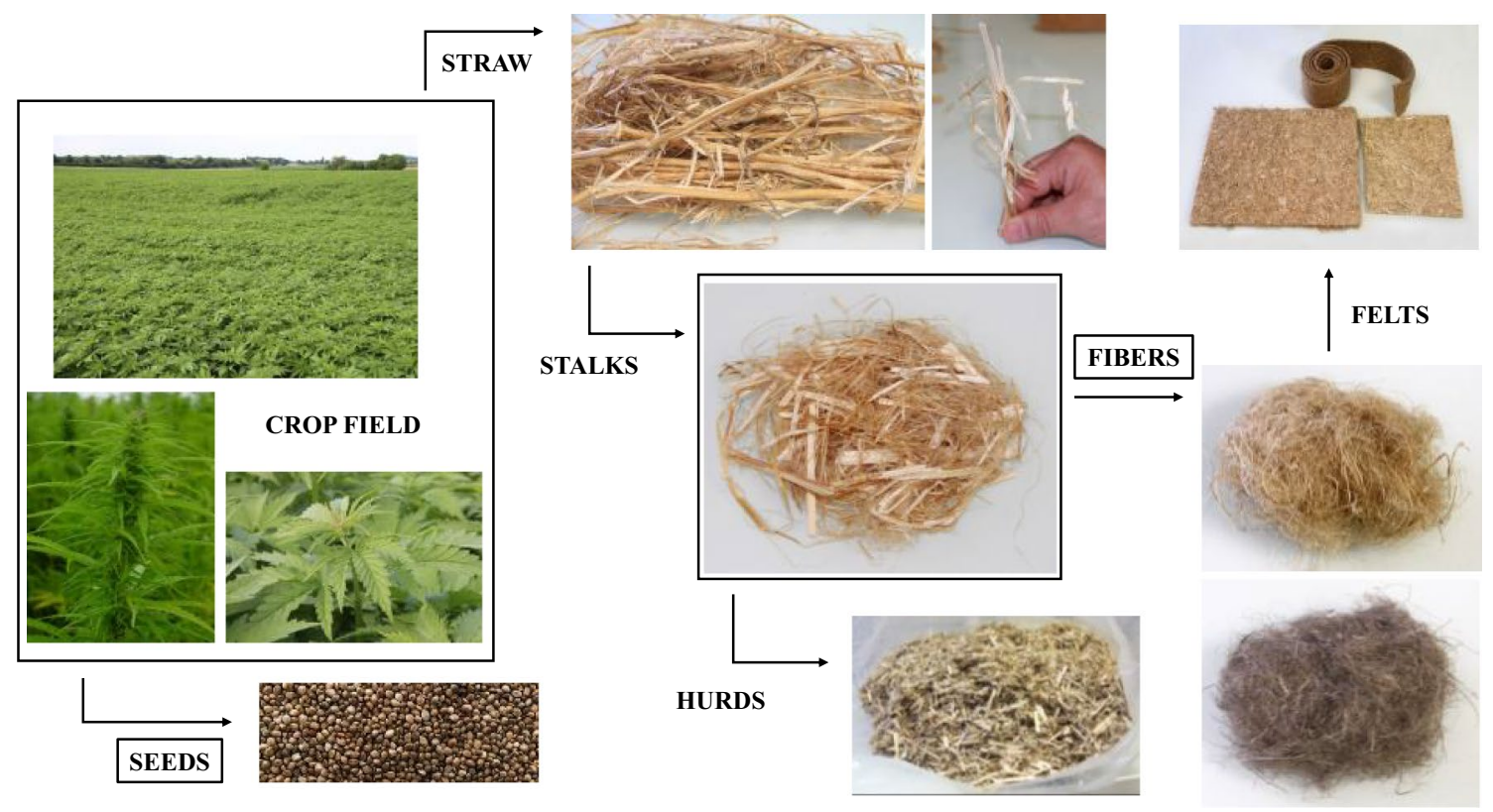

Fig. 2 Industrial hemp products; Cannabis sativa $\mathrm{L}$. is the source of two types of natural fibers: long bast fibers in fibrous form and woody short core fibers, called hurds or shives, in granular form; the hemp

relevant references published over the last decade. This article is an abridged version of the chapter published by Crini et al. (2020) in the series Sustainable Agriculture Reviews.

\section{Hemp fibers in industrial applications}

\section{Textiles, fabrics and furniture}

Hemp fiber has served humanity for thousands of years to create textiles, fabrics, ropes, yarns, rugs, and canvas. The fiber can be spun, then woven or knitted into many fabrics suitable for durable and comfortable clothing. Hemp fiber was indeed a common material for clothing because of its durability and versatility until the cotton industry grew stronger all over the world gained (Small and Marcus 2002; Liberalato 2003; Wang et al. 2003; Kozlowski et al. 2005; Sponner et al. 2005; Thomas et al. 2011; Bouloc 2013).

Hemp fiber is very strong compared with other natural fibers such as cotton, flax and nettle. So, historically, the fiber has also long been widely used in ropes, rigging, net, and sail production. Other advantages are its flexibility, strength, and resistance to water damage. Thus, in past centuries, hemp was extremely important to the Navy, the shipping trade, and also fishing. Christophe Colomb sailed to America on ships rigged with hemp (Bouloc 2013). The oldest known woven fabric was made from hemp, as were Levi Strauss' original denim jeans, and the first American flag. stem photography shows bark, secondary bast fibers and woody core. Source: G. Crini, Chrono-environnement, Besançon, France

Nowadays, hemp can be used to make a variety of similar but more durable fabrics than cotton (Amaducci and Gusovious 2010; Müssig 2010; Bouloc 2013). Numerous consumer brands such as Adidas, Patagonia, and commercial channels have added hemp products to their offer that help to popularized hemp as a clothing fiber or accessory.

Currently, clothing is a high profile market for hemp. Hemp fibers find numerous applications in textiles and the possibilities for hemp fabrics are immense: apparel, jeans, sport clothing, bags, hats, cushion covers, blankets, shoes, socks, accessories, ropes, yarns, rugs, furniture and home furnishings, and also hemp jewelry, e.g., bracelets, necklaces, anklets, rings, watches, and other adornments (Amaducci and Gusovious 2010; Müssig 2010; Bouloc 2013; Kostić et al. 2014; Bhavani 2015; Pil et al. 2016; Zhang et al. 2016; Bran et al. 2017; Lamberti and Sarkar 2017; Mirski et al. 2017; Rijavec et al. 2017; Gedik and Avinc 2018).

Textiles are easy to produce, durable, breathable, versatile, biodegradable, having strong thermal qualities. Fabrics have the best capacity ratio compared to other fibers, meaning they keep the wearer cool in the summer and warm in the winter. Preference for hemp textiles in summer is often associated with their excellent hygienic properties. However, natural fibers without modification do not provide good UV protection. The fabrics are also antimicrobial and hypoallergenic, as well as resistant to mold. Fibers are also more resistant to weather and ultraviolet rays than cotton and silk. Hemp clothing is stronger and more durable than cotton clothing and does not deform as easily. Apparel made 
from hemp merges easily with dyes and does not discolor easily. No difference between hemp and cotton fabrics in terms of colorfastness to crocking, oily stain release, flammability, tearing strength, breaking strength and elongation, as recently pointed out by Lamberti and Sarkar (2017). Fibers can also be mixed with other materials to create clothing hybrids, e.g., fibers can be blended with cotton or linen for specific textures and performance.

For all these reasons, hemp is also an eco-friendly fabric for upholstery and furniture: home furnishing textiles, seating, tables, fashion accessories, mirrors, wall decorations, decorative objects, etc. Finished goods such as clothing, shoes and hats are made from $100 \%$ hemp or combined with other natural or synthetic fibers. Hemp is also a viable and excellent fiber for making rugs, pure hemp carpets, and similar textiles. However, two main problems often cited are their primarily higher cost and the need for manufacturing machinery to be adapted.

Cordage is an age old use for hemp fiber. While its use in the marine world has largely being replaced by cheaper, long-lasting and lighter synthetics, hemp rope still has its uses. It is well known that, due to its coarser texture, hemp rope can bind against itself for better knot stability, and this is useful in some situations. Hemp yarn is used for crafted jewelry because it is smooth, consistent, strong and comfortable in contact with the skin. Hemp twine is also interesting in crafting, gardening and landscaping.

Hemp oil is also an interesting product for furniture, leather or wooden floor, e.g., Wise Owl Hemp. Pure oil, completely free of solvents or other chemical additives and preservatives, can be used to seal raw wood and furniture pieces. The advantages cited are: $100 \%$ natural, safe quality food, biodegradable, easy to use, both interior and exterior use, conservation of the initial color of wood, water and alcohol resistance, ideal for food surface, etc. Hemp oil for furniture is derived from the same pressed hemp seeds used for food-grade edible oils, the only difference being the level of amino acids, which affects the drying time. The odor of the oil is much like crushed walnuts. Hemp oil may be used on finished wood to clean and protect or on unfinished wood to bring out the richness of the wood grain. It makes an excellent sealant over stained furniture.

However, although the hemp markets for clothing, furniture, luxury and fashion have seen a strong increase in popularity, the markets for specialty fibers tend to be cyclical. In addition, due to the rise in the industrial use of cotton followed by synthetic fibers in Europe, users had to turn to importing hemp, particularly from Asia. Nevertheless, several European companies and cooperatives, particularly in France, are carrying out several research and development programs for the reintroduction of European hemp into the textile industry because the possibilities for hemp fabrics are immense.

\section{Paper}

Historically, hemp has been used to make paper for thousands of years. In ancient China, hemp fiber was primarily produced for use in paper scrolls (Robinson 1996). As already mentioned, the first copies of the Bible were made of hemp paper and the American constitution was written on hemp paper (Ranalli and Venturi 2004). Hemp paper was more resistant to decomposition, stronger, especially when wet, less prone to yellowing than tree-based paper (Harris et al. 2008; Ranalli and Venturi 2004; Bouloc 2013).

After the "rediscovery" of hemp in Europe in the 1990s, hemp fibers were mainly used for the manufacture of special pulp and paper. Hemp as non-wood fiber is indeed an ideal yield raw material for making specialty paper due to its highquality physical properties of its pulp, and its tensile strength (Ranalli and Venturi 2004; Harris et al. 2008; Barberà et al. 2011; Bouloc 2013; Miao et al. 2014; Feng and Zhang 2015; Danielewicz and Surma-Slusarska 2017; Przybysz Buzala et al. 2017; Yu et al. 2017; Bajpai 2018).

Compared to conventional wood paper, hemp paper has superior qualities like higher strength, length and fineness. Hemp's long bast fibers make a fine quality paper that is naturally acid free. Hemp paper uses less chemicals in production than tree-based paper. It does not become yellow and brittle or disintegrate over time like conventional paper. It is a faster and more efficient way of growing fiber than the use of trees. The paper is also of high quality and durable for long-term storage for forms, currency paper and cigarettes production. However, it is more expensive, i.e., the cost of hemp pulp is three to six times higher compared to conventional wood-based pulp production. This can be explained by the fact that the use of hemp in papermaking is mainly concentrated on bast fibers, the woody core of the plant being often considered as waste. The bast fibers are only a small part of the plant stem (hemp stalk averages around $20-30 \%$ bast fibers), and separation tends to lead to high production costs. Another difficulty which causes an increase in the hemp pulp price is that the hemp is harvested once and needs to be stored all year long.

The applications are limited to a very few applications such as technical filters, bank notes, bible paper, dielectric and medical paper, and cigarette paper, due to the high price of hemp pulp (Yu et al. 2017). Specialty papers also include teabag paper, coffee filter, specialty non-wovens, greaseproof papers, carbon tissues and condensing tissues. Currently, the only well-established market for hemp pulp is the cigarette paper market (European Industrial Hemp Association). In the production of cigarette paper, all the fiber in the stem can be used.

Nowadays, industrial hemp is not competitive on the paper market for the production of conventional papers, because the market is cyclical. For instance, kenaf has many 
economic advantages over hemp as non-wood fiber for the paper industry. Perhaps, the growing market for recycled pulp and paper may increase the demand for agricultural fibers to strengthen recycled papers. Similar to textiles, hemp fibers can be used as blends with other pulp fibers such as wheat straw or flax or even recycled wood, in order to increase paper performance, strength and recyclability. In addition, core and whole stalk are proposed to make lower end paper products, depending on available pulping technology that is tooled to process hemp efficiently. These markets can grow (Danielewicz and Surma-Slusarska 2017; Przybysz Buzala et al. 2017; Yu et al. 2017; Bajpai 2018).

Another promising market is filtration. Through comparison of oil filtration properties and air filtration properties with commonly used automobile engine oil/air cotton paper filtration materials, Feng and Zhang (2015) reported that hemp paper had the smaller thickness, weight, mean pore diameter, porosity and oil/air penetration, while the better oil/air filtration efficiency and higher pressure drop. Due to the higher filtration efficiency of hemp papers and green, biodegradable, sustainable resources of hemp plants in the case of environmental requirements, a pilot trial hemp paper automobile engine oil filter was successfully manufactured. The results indicated that hemp papers had better oil/air filtration properties than cotton paper in practical application.

\section{Insulation and building materials}

Compared to the traditional synthetic fiber materials, natural fibers such as hemp fibers represent a sustainable solution to be used for different applications in building construction, mainly because of their hygrothermal properties. Hempbased materials can be manufactured into a variety of commercial products of various densities that resemble concrete, wood, and even plastic. In addition to the environmental value of using plant matter, these materials benefit from the mechanical strength of the hemp fibers.

Bio-based materials containing hemp also offer many other advantages over more established mineral and oilbased alternatives. These building materials are durable, lightweight, affordable to produce, water-proof, fire-proof, self-insulating, resistant to mold, moisture-proof, highly breathable, and resistant to pests, and they have good heat resistance in winter time and cool in summer. The materials are also ideal for resisting damage caused by earthquakes, floods or other natural disasters (Shahzad 2012).

It is also claimed that hemp building materials trap carbon dioxide, making their use attractive from an environmental perspective (Zabalza Bribián et al. 2011; Ip and Miller 2012; Amziane and Arnaud 2013; Collet et al. 2013; Dubois et al. 2014; Latif et al. 2015; Jami et al. 2016, 2019; Jiang et al. 2018; Miller 2018; Moujalled et al. 2018; Pittau et al. 2018).
However, the main disadvantage is the lack of guarantees in terms of durability (Walker et al. 2014; Arizzi et al. 2016).

As industrial products available on the market, hempbased materials are subject to a number of National and European technical regulations and have been approved officially for use in the construction industry. Hemp fibers are mainly used for insulation, e.g., insulating material and insulation wool, and/or construction. Insulation is the second important application for hemp fibers today (European Industrial Hemp Association). These fibers can also be used for acoustic and soundproofing purposes. This is an area of research that is currently in full expansion.

With the exception of hemp seed, which has no significant use as a building material, hemp straw can provide two products/co-products for the construction industry: (1) the bast fibers and (2) the woody core of the stalk used to produce hurds. Due to their different properties, these two products are used to produce different construction and insulation materials (Figs. 3 and 4).

The materials can be made from the compressed inner short hemp fiber. The outer hemp fibers can also be used like straw in bale construction paired with mud for an old-style cob building. Hemp boon, obtained after crushing hemp woody core of the stem, is useful for thermal insulation composite production due to their small-pored structure.

High-quality building blocks are produced by mixing a binder, e.g., lime, clay or cement, with non-fibrous hurds particles (Elfordy et al. 2008; Pretot et al. 2014; Walker and Pavía 2014; Walker et al. 2014; Kinnane et al. 2016; Gourlay et al. 2017; Jami et al. 2019). These materials are biocomposites referred to hemp concrete, hempcrete or hemp-lime (Fig. 6). Hemp shives in combination with lime is currently

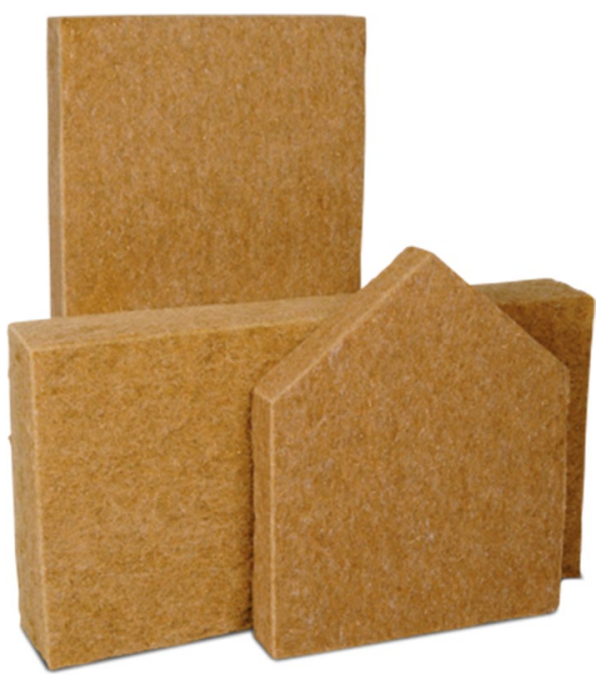

Fig. 3 Hemp panel wallboards made from 100\% fibers. Source: G. Chanet, Eurochanvre, Arc-les-Gray, France 
another increasing market for construction, e.g., stucco/plaster production, caulking.

Hemp provides all sorts of building materials: blocks and bricks, slabs and paneling, wallboard (Fig. 5), fiberboard, roofing tiles, and insulation products (Fig. 6). Hurds/shives are used to produce light concretes and mortars for different end uses, e.g., wall construction, insulation, underfloor, etc.
Fig. 4 Hemp-based products for insulation or building. Source: G. Chanet, Eurochanvre, Arcles-Gray, France

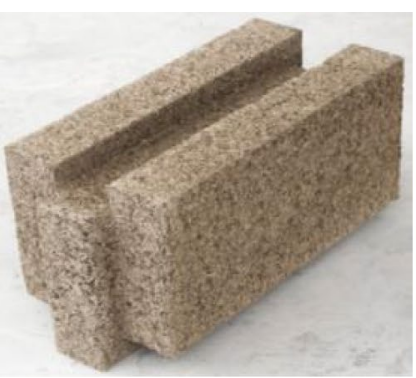

concrete block

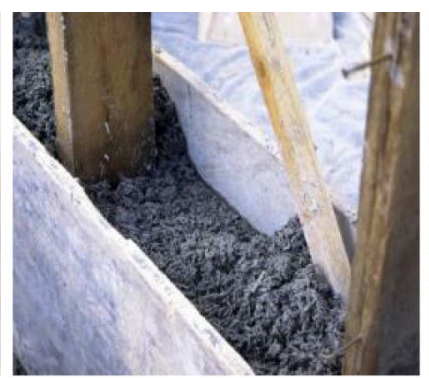

concrete wall

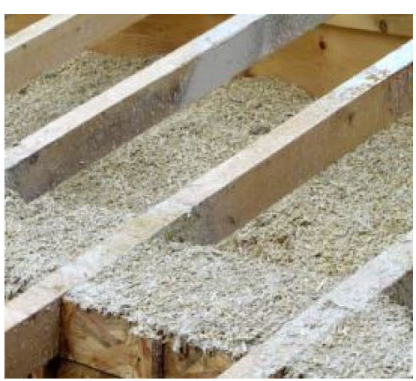

roof insulation

Fig. 5 A half-timbered building in Normandie, France, dating from the early nineteenth century. The walls and slabs were renovated using different solutions based on hemp concrete. Source: with the kind courtesy of Florence Collet (Rennes, France) and Yacine Aït Oumeziane (Belfort, France)

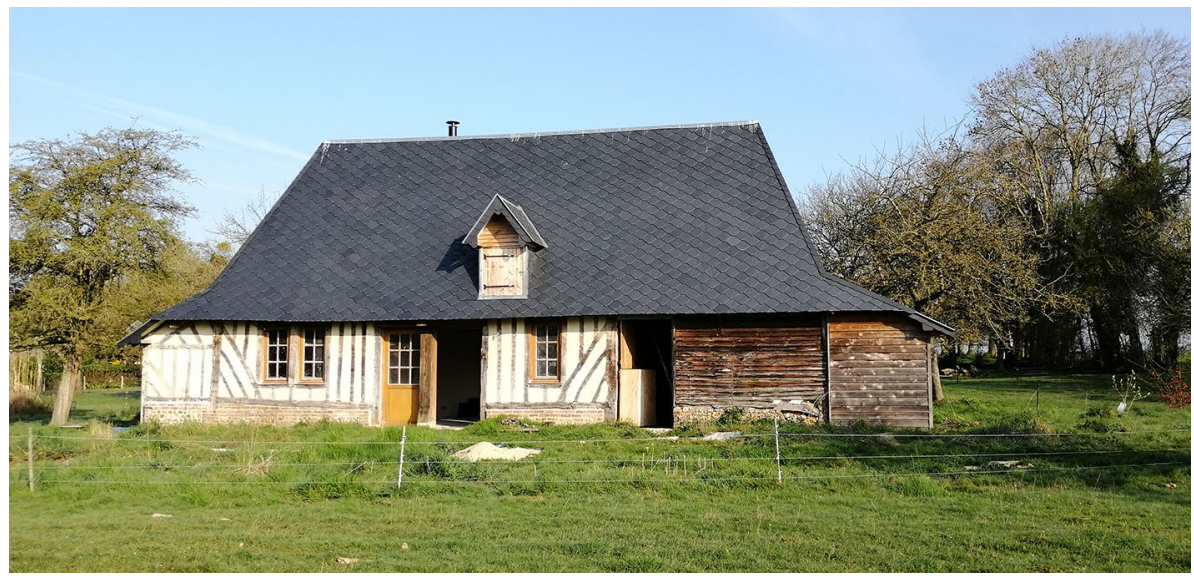

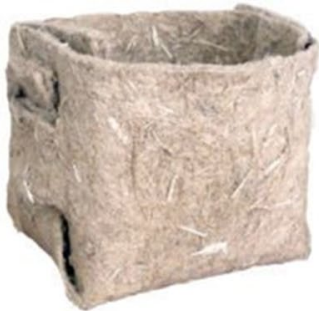

vegetable pot

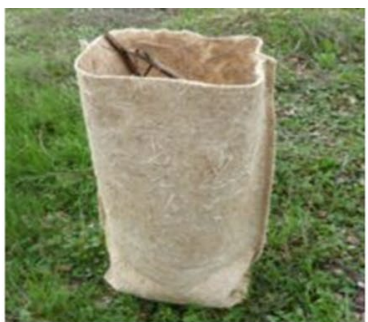

ecological grow bag

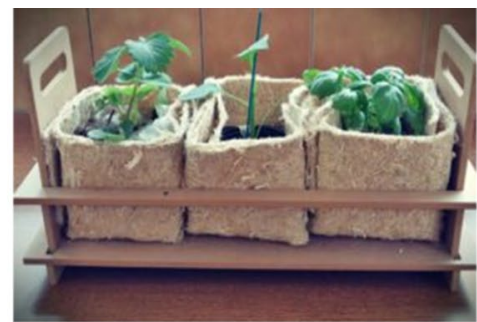

potted plants , plant balcony
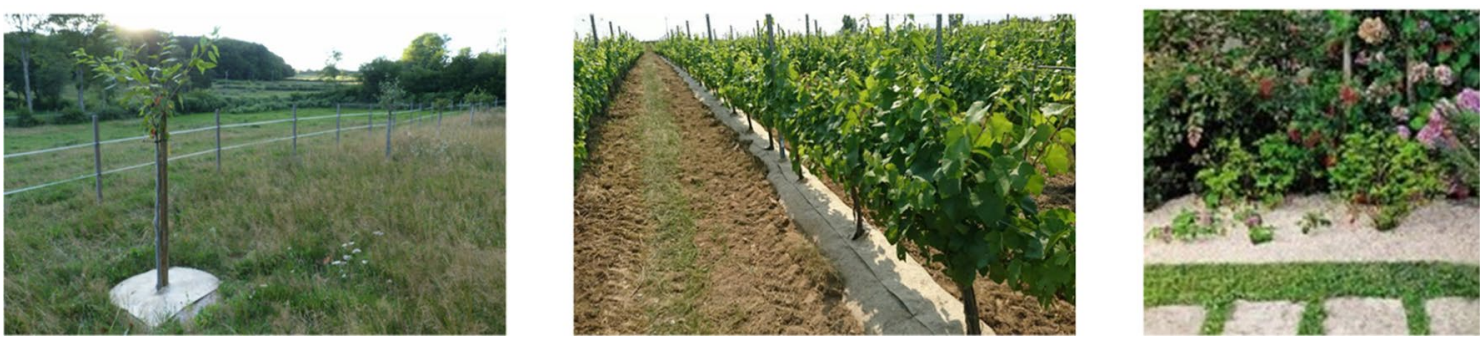

mulch cloth: shrubs, strawberries, salads, gardens

Fig. 6 Hemp-based products in felt form used in horticulture. Source: G. Chanet, Eurochanvre, Arc-les-Gray, France 
Due to their low density, elasticity, permeability, and insulating properties, hurds are also used for production of particle boards (Elfordy et al. 2008; Bouloc 2013; Walker et al. 2014; Cigasova et al. 2015; Ingrao et al. 2015; Fangueiro and Rana 2016; George et al. 2016; Jonaitiene et al. 2016; Kinnane et al. 2016; Niyigena et al. 2016; Fernea et al. 2017; Gourlay et al. 2017; Kiruthika 2017; Liuzzi et al. 2017; Mirski et al. 2017; Chernova et al. 2018; Kallakas et al. 2018; Nováková 2018; Pichardo et al. 2018; Usmani and Anas 2018).

These environmentally friendly building materials are suitable for the construction of houses (e.g., Chanvribat ${ }^{\circledR}$, Béton Chanvre Tradical ${ }^{\circledR}$ France). Hemp-based materials can indeed replace wood and other materials used to build homes and other structures including foundations, underfloor, walls, shingles, paneling, pipes, and paint.

Houses can be made nearly $100 \%$ out of hemp materials: walls can be hemp wallboard (Fig. 5) or hemp cement for walls (Fig. 6); insulation can be made of hemp, e.g., hemp cement to insulate under the floor boards; hemp bricks and hemp plaster; pipes can be made out of hemp plastic; paint made with hemp oil; hemp carpet for interiors, and even a hemp roofing material.

Hemp concrete was developed in France in the 1990s as an alternative to wattle and daub for the restauration of historic building (Bouloc 2013), in particular with the works of Charles Rasetti on the restauration of a medieval timber framed building, "Maison de la Turque" at Nogent-sur-Seine in 1987. At that time, other projects on the renovation of historical buildings based on hemp-lime use, e.g., in Versailles, were also developed (Canosmose ${ }^{\circledR}$, IsoChanvre ${ }^{\circledR}$, ChanvriBloc $\left.{ }^{\circledR}\right)$. However, Charles Rasetti was the first to patent hempcrete in 1986, Canobiote ${ }^{\circledR}$ and Canamose $^{\circledR}$ (International Hemp Association). Canamose ${ }^{\circledR}$ was a lightweight concrete made with hemp hurds and natural lime, which might be used for all types of nonload-bearing masonry, and was perfectly suited to walls sectioned with wooden supports. Canobiote ${ }^{\circledR}$ was hemp hurds coated with mineral salts, which was an effective process for the insulation of wood-framed, closed lofts and floors intended for regular use.

Currently, hemp concrete/hempcrete is commonly used in Europe, e.g., in France (Fig. 5), England, Germany, Ireland, Belgium, Luxembourg and Switzerland, as a multifunctional ecological material for building applications. Hemp-lime construction had also been adopted in North America (Quebec), South Africa, Israel, Australia and New Zealand.

The advantages often cited are: excellent thermal insulation properties, low thermal conductivity, high hygrothermal efficiency, breathability, low environmental impact, e.g., in terms of emissions of greenhouse gases, interesting acoustical properties, and particular hygrothermal behavior enabling a natural moisture regulation (Arnaud and Gourlay 2012; Mazhoud et al. 2017; Ait Oumeziane et al. 2016).

Hemp-lime is also a cheap and low density material with associated low thermal conductivity depending on the density and moisture level, and it presents an interesting balance between low mass and heat storage capacity compared with classical insulation materials. It is considered as a sustainable, carbon negative and low embodied energy construction material (Zabalza Bribián et al. 2011; Latif et al. 2015; Bouloc 2013; Kinnane et al. 2016).

\section{Composites and plastic alternatives}

Hemp fibers are used not only for insulation but also for the production of composites in the automotive, furniture and fashion industries where synthetic fibers are replaced by hemp fiber. Indeed, bast fibers are desirable for composite/ biocomposite production due to their length and strength, while hurds, the by-products of extracting the bast fibers from the stalk, are interesting for particle board and biodegradable plastic production.

Active research continues in these areas (Faruk et al. 2012; Shahzad 2012; Bono et al. 2015; Cigasova et al. 2015; Fernando et al. 2015; Pil et al. 2016; Ummartyotin and Pechyen 2016; Gallos et al. 2017; Lamberti and Sarkar 2017; Liu et al. 2017; Mirski et al. 2017; Nunes 2017; Nurazzi et al. 2017; Chernova et al. 2018; Karaduman et al. 2018; Musio et al. 2018; Sarasini and Fiore 2018; Sepe et al. 2018; Spierling et al. 2018; Usmani and Anas 2018; Väisänen et al. 2018; Chauhan et al. 2019; Kumar et al. 2019; Gholampour and Ozbakkaloglu 2020).

In 1941, Henry Ford used hemp-based plastics to build car doors and fenders. He produced a prototype, the Hemp Body Car, that showed the great potential of hemp used in combination with plastic technology, indeed $70 \%$ of straw mixed with a plastic composite. Ford demonstrated the strength of the hemp composite by hitting the car with a club and leaving no trace in the bodywork, a scene immortalized by a famous photograph (The Collections of the Henry Ford).

Ford predicted that his prototype "would be lighter, sager and less expensive" (New York Times, February 2, 1941). However, at that time, the technology was never put into mass production (Small and Marcus 2002). The car also was to run on hemp-ethanol. Ford was a visionary.

Currently, industrial hemp presents great opportunity for supplying a sustainable and carbon positive source of plasticizing material and several hemp-based plastics or bioplastics are on the market, e.g., in the automotive sector. Hemp can be processed into different forms used in automotive interior and exterior applications, e.g., carmakers are currently using hemp composite inserts, trunks, head-liners, spare wheel covers, parcel trays, etc. An important market 
is the press molding market for interior applications: door panels and car boot trims, rear shelf and roof liner panels, dashboards, pillar trims, seat shells, under bodies and other applications.

The biocomposites and bioplastics are price competitive in high-quality interior concepts although hemp fibers are also in competition with flax, jute and kenaf fibers. They are also considered less expensive than fiberglass counterparts and show the favorable mechanical properties of rigidity and strength in combination with low density.

Another interesting advantage can be cited: The material does not splinter and leaves no edges which is an important characteristic, especially in the case of automobile accidents. It is also claimed that hemp fiber-reinforced plastics show energy and greenhouse gas savings in comparison with their fossil-based counterparts. After use, their incineration with energy recovery shows higher energy and emissions of greenhouse gases savings compared to an analysis from cradle-to factory gate.

The bioplastics containing hemp are, for example, used to replace synthetic polymers and copolymers such as polyacrylonitrile-butadiene-styrene in dashboards. These products are hemp fiber-reinforced polypropylene compound and are designed for automotive structural parts by injection process. They are mainly used in the German automotive industry (e.g., BMW, Mercedes, Volkswagen Golf), followed by the French (e.g., Peugeot 308, Megane, DS7 Crossback) and Italian (e.g., Alfa Roméo Giulia) industries. An example is Refine ${ }^{\circledR}$ Hemp-PP for the inserts and top roll of the door panels in the Peugeot 308. Another example is NAFILean ${ }^{\mathrm{TM}}$ used as biocomposite in the dashboard of the Alfa Roméo Giulia.

Hemp fiber-reinforced plastics are also used in the production of furniture or other consumer products such as briefcases, glasses and fashion accessories. Biocomposites are proposed for high-performance products like yachts, composite sink basin, sunglasses and ski goggles $\left(\right.$ HempEyeWear ${ }^{\circledR}$ ), or trays for grinding disks. Shives are proposed for insulation of airline seats. A hemp-plastic resin, HempStone ${ }^{\mathrm{TM}}$, is proposed for use in musical instruments, loudspeakers, and furniture, e.g., tables and chairs.

Khattab and Dahman (2019) recently reported the production and recovery of poly(3-hydrobutyrate) from agro-industrial residues of hemp hurd biomass, to prepare ecological bioplastics with low environmental impact. Their technology focused on converting wastes into useful biomaterials such as poly(3-hydrobutyrate), contributing to reduce the environmental footprint, through the concept of circular economy. Poly(3-hydrobutyrate) is a biodegradable and biocompatible material which stands out as replacement for fossil-derived plastics. However, much work is still needed to reduce the cost of this environmentally friendly biodegradable plastic. This polymer is also proposed for absorbable sutures, scaffolds, heart valves, and cardiovascular tissue supports.

This research can lead to new markets.

\section{Uses of hemp for domestic animals}

As already mentioned, fiber processing yields a significant quantity of hurds, corresponding to some $60 \%$ of the weight of the plant. Hurds are often considered as a by-product with no worth (Small and Marcus 2002; Gibson 2006; Fike 2016). Indeed, they have a high bulk to price ratio, even when compressed, and cannot be economically transported very far. Today, special uses such as animal bedding and horticulture have become widespread and popular.

Due to its hydrophilic properties and its ability to absorb water, a valuable market for hurds is indeed in high-quality bedding for horses, poultry and pet litter (Small and Marcus 2002). The hurds are more absorbent than straw, about fourfold, and need to be changed less often. They have better odor-suppressing abilities and are less allergenic than alternatives such as wood shavings, straw and hay. In addition, hemp, once on the ground, provides a stable surface that does not tend to move or slip. It is comfortable for horses, for it made up of small particles. However, the bedding is likely to be ingested if the horses are hungry.

Cat litter made from granules of hemp powder absorbs urine and feces and is particularly good at capturing odors. Cleaning of the litter tray is easy as the granules compact down after becoming soiled. They can then be used as a fertilizer of composted down. Hemp straw is used in cattle sheds as an alternative to barley or wheat straw. Small pieces of hurds are suitable as bedding for small mammals, e.g., hamsters, guinea pigs, chinchillas, mice, rats, and pigeons, as well as rabbits and snakes (Small and Marcus 2002; Bouloc 2013; Fike 2016; Johnson 2018).

\section{Horticulture and market gardening}

Hemp hurds are also used for horticultural mulch. Hemp mulch, like traditional mulch, is primarily used as a surface application for gardens that include vegetable, flower and even container plants such as shrubs. Hemp mulch is easy to handle and is not prone to caking on the surface. It does an excellent job of maintaining soil moisture, minimizing erosion, and suppressing weed growth and seed germination. Indeed, it eliminates the need for manual or chemical weeding control and acts as a screen to keep seeds from germinating. Its water absorption capacity cuts down on the need for watering, as the shives keep the ground damper for longer. Hemp mulch is superior in insulating the soil from the hot sun and cold winter, especially frost protection. Product is also $\mathrm{pH}$ neutral, compatible with the $\mathrm{pH}$ of the soils, fully biodegradable and add humus to soils, i.e., as it decomposes, 
it helps to enrich the soil (Bouloc 2013; Cherney and Small 2016; Chandra et al. 2017).

Several manufacturers also offer hemp-based fleeces in the form of felt or mulch cloth, supplied mostly in rolls, e.g., Geochanvre ${ }^{\circledR}$ products, France. These materials are a biodegradable layer of fibers used to create a suitable planting environment that warms the soil, retains moisture, and deters weeds. It is also an ecological protection and an alternative to the use of herbicides. Figure 6 shows hemp-based products in felt form used in horticulture. They are considered as agricultural textiles or geotextiles (Small and Marcus 2002). For potted plants, they are also used for plant propagation and as a substrate (Kolodziejczyk et al. 2012; Jonaitiene et al. 2016).

Used as mulch mats for green areas, e.g., along highways or on roadsides against weed invasion, these biodegradable felts constitute an effective and environment-friendly alternative to plastic mulching. The plants are inserted through the mat, which promotes rapid growth. Once established, the constituent parts of the felt degrade, leaving natural organic matter for continued protection. Hemp fleeces can also be used in earthworks and water engineering, for example, to protect from erosion or to divide soil layers. These products show high saving potentials in terms of energy and emissions of greenhouse gases compared to polypropylene fleece (Kolodziejczyk et al. 2012; Fike 2016; Jonaitiene et al. 2016; Johnson 2018).

\section{Hemp products in animal nutrition and food industry}

Hemp seed is a valuable food for both human and animals. Since the 1990s, in several developed countries such as Canada, USA, France, UK and Germany, the seed is gradually making a comeback as ingredients in food products, beverages or as nutritional supplements (Callaway 2004; Kolodziejczyk et al. 2012; Leson 2013; Russo and Reggiani 2013; Girgih et al. 2014c; The and Birch 2014; Bono et al. 2015; Dunford 2015; Andre et al. 2016; Fike 2016; Hartsel et al. 2016; The et al. 2016; Mikulcová et al. 2017; Pihlanto et al. 2017; Frassinetti et al. 2018; Johnson 2018; Devi and Khanam 2019a, b; Fiorini et al. 2019; Mamone et al. 2019; Wang and Xiong 2019). Currently, there are a worldwide interest in health-promoting functional foods and dietary supplements. France is the world leader in hemp seed production (European Seed Certification Agencies Association, www.escaa.org).

The renewal of hemp-based foods was due to the fact, in the 1990 s, greater attention was paid to the nutritional composition of hemp seeds, particularly of their fatty acid spectrum, which have been found to have a unique and probably beneficial balance of so-called omega- 3 and omega- 6 fatty acids for health.

Other reasons can also be mentioned such as the growing interest in the valorization of agro-food by-products, the search of new sources of proteins, the production of bioproducts, e.g., bioactive peptides, natural antioxidants and new natural beverages (Fig. 7), and different concerns such as food allergies, animal welfare, and the negative impact on the environment associated with animal-derived proteins (Pihlanto et al. 2017).

For instance, bioactivities claimed in numerous publications are antioxidative, antihypertensive, antimicrobial, anticholesterolemic, and also antitumoral activities, which have attracted growing attention not only from scientists but also from the food industry and consumers. However, more studies need to be done on these health benefits (Girgih et al. 2014a, b; Pihlanto et al. 2017).

Most hemp seeds are used as whole seeds, followed by hemp seeds for oil and de-hulled seeds. The whole seed, the cheapest and less processed product, is mainly used for animal feed. In contrast, the de-hulled hemp seed, first produced in quantity in Europe, is mainly used for human food (Small and Marcus 2002). The most expensive product, hemp oil, is almost entirely used for human food and cosmetics.

\section{Hemp as a source of feed additives}

Currently, hemp is a feedstuff for animal diets (Bouloc 2013; Leson 2013; Fike 2016; Johnson 2018). Four main essentially different types of materials derived from the plant may be used: hemp seed, hemp seed cake/meal, hemp seed oil and whole plant. Further products such as hemp flour and protein isolate from seeds can also be used.

Seed and seed cake are particularly interesting as feed materials for all animal species, i.e., birds, ruminants, pigs, horses, poultry, pigeons, fishes (Bouloc 2013). Birds and fish feed are the main market for hemp seeds in animal feed. Seeds play an important role in the animal nutrition, providing mineral nutrients, vitamins, dietary fibers, as well as biologically active compounds. Hemp seeds are also used by anglers as bait. The whole plant, including stalk and leaves, is also used for ruminants and horses. Cannabinoid-based formulations containing protein powders such as EliXinol ${ }^{\mathrm{TM}}$ are available as dog treats.

Given the high value of the oils, future use of products in animal feeds may nevertheless be limited to the by-products produced after the oils have been extruded (Leson 2013; Fike 2016). Indeed, the production of plant seed oils generates tons of processing wastes called seed cakes. These byproducts are then further processed into animal feed due to their high protein and energy contents.

In the last decade, the potential of hemp as an animal feed is dwarfed by its value to the foods, supplements, 

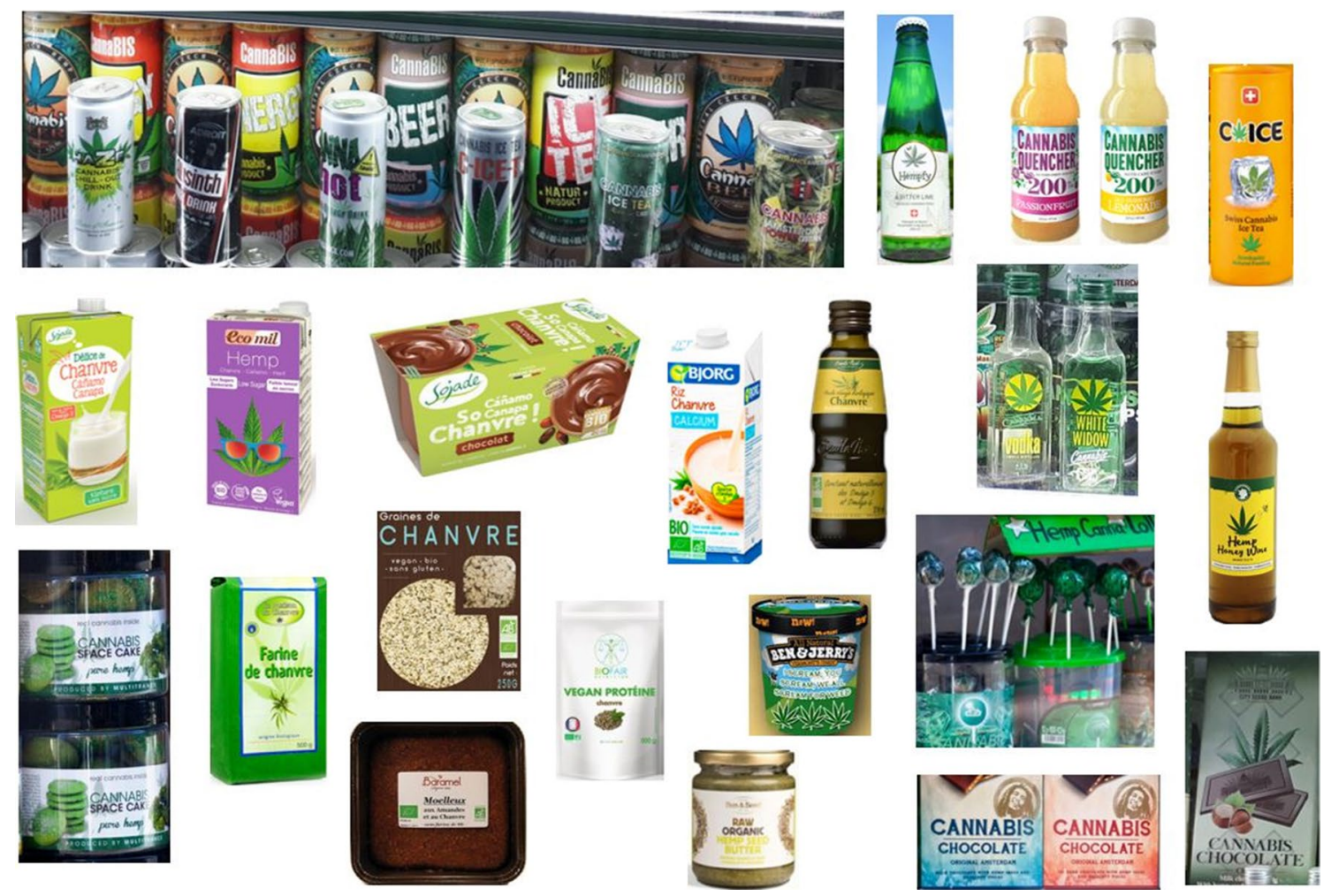

Fig. 7 Hemp-based foods and beverages. Source: G. Crini, Chrono-environnement, Besançon, France

neutraceuticals, and cosmetics industries that create products and biologically active compounds with expected health and diseases-prevention benefits for human use, nutrition or consumption. These markets are more lucrative (Johnson 2018).

\section{Hemp seed and essential oils as a source of human food additives}

All hemp food products originate from hemp seeds, i.e., seeds themselves and its products such as meal, flour and protein powder, oil and bioactives substances (Callaway 2004). All these products are achieving a growing popularity in human nutrition as an important food resource (Andre et al. 2016; Frassinetti et al. 2018), the principal product made from hemp seeds today being undoubtedly the seed oil (Johnson 2018; Leonard et al. 2020).

Demands for natural foods, functional foods, plantderived proteins, gluten-free products, and bioproducts in worldwide markets have been a major driver of hemp production (Fike 2016). Growth in this market is not surprising given that hemp seeds have excellent fatty acid profiles and protein qualities, and have been used for centuries to treat various disorders (Leson 2013).

In the last years, an increasing use of hemp seeds was observed, due to their nutritional and beneficial properties among people interested in improving and maintaining their health status by changing dietary habits (Fike 2016; Pihlanto et al. 2017; Frassinetti et al. 2018; King 2019). Indeed, they play an important role in the human diet and are an excellent source of nutrients, containing all essential amino acids and fatty acids in sufficient amount and ratio to satisfy the dietary human demand.

Hemp seeds contain more than $30 \%$ of oil, i.e., $320-380 \mathrm{~g} / \mathrm{kg}$ oil, $80 \%$ of which is polyunsaturated fatty acids (Callaway 2004; Rodriguez-Leyva and Pierce 2010; Russo and Reggiani 2013; The and Birch 2014; The et al. 2016; Pihlanto et al. 2017).

The oil as functional food is an exceptionally rich source of the two essential fatty acids, linoleic acid or omega- 6 and alpha-linolenic acid or omega-3. The omega6-to-omega-3 ratio in hemp seed oil is between 2:1 and $3: 1$, which is considered to be optimal for human health. A 2.5 value is found in Mediterranean and Japanese diets where the incidence of heart diseases has been historically low (Russo and Reggiani 2013).

The metabolites of the two essential fatty acids, i.e., gamma-linolenic acid and stearidonic acid, are also present in oil. Hemp currently is the only known natural source of gamma-linolenic acid, a widely consumed supplement with numerous health benefits, e.g., to treat eczema and mastalgia. 
A nut also contains $25-35 \%$ of lipids, $20-30 \%$ of carbohydrates, $10-15 \%$ of insoluble dietary fibers, and $20-25 \%$ of proteins with considerable amounts of vitamins, e.g., vita$\min \mathrm{E}(90 \mathrm{mg} / 100 \mathrm{~g})$ and a rich array of minerals such as phosphorus, potassium, magnesium, sulfur, calcium, iron, and zinc (Callaway 2004; Rodriguez-Leyva and Pierce 2010). The seed, and thus oil, does not contain THC. Hemp seeds are rich in proteins and contain absolutely no cholesterol. The two main proteins are globulin/edestin (60-80\% of the total protein content) and albumin, and both of the proteins are easily digested in the human gastrointestinal tract (Malomo and Aluko 2015a; Pihlanto et al. 2017).

Hemp seed protein is considered as a useful food ingredient and a suitable alternative source of functional proteins to traditional ingredients. However, there is scanty information on the structural and functional properties of the seed globulin and albumin fractions. Hemp seeds also contain nutritionally significant amounts of all essential amino acids, especially high levels of the amino acid arginine.

For all these reasons, hemp seed oil is marketed as a nutritional additive and a health-promoting product. Oil from hemp seeds is far more valuable in terms of concentrated nutrients and proteins than soybean the nearest vegan alternative.
To retain its valuable constituents, hemp seed oil must be un-refined and cold-pressed from non-heat-treated seed. Before treatment, hemp seed oils are off-yellow to dark green color. Purified or refined oil is clear and colorless and has a pleasant, nutty taste/flavor. It is a versatile product, used in liquid or capsule form (oil gel caps). It is best consumed raw, in salad dressings or as a garnish or mayonnaise, and it can be poured over pasta to give extra flavor. Indeed, due to its precious fragile essential fatty acids, it is better not to cook it, e.g., this can create toxic trans-fatty acids. Unsaturated oils also oxidize very easily, which is why such oil quickly becomes rancid on exposure to the air. Hemp seed oil is fairly unstable and becomes rancid rather quickly unless preserved.

Other products being produced today include hemp sauce, butter, hemp meal and gluten-free flour, protein powders (EliXinol ${ }^{\mathrm{TM}}$ ), pasta and spaghetti, sorghum and hemp cakes (Fiorentini ${ }^{\circledR}$ ), snack foods, energy bars, hulled hemp seed, muesli, toasted hemp seeds, burger mix, crackers (FoodsAlive $\odot$ ), pancakes, porridge, fruit crumble, chocolate (Fig. 8), sweets (Plus ${ }^{\mathrm{TM}}$ ), sour hemp gum, frozen dessert and ice cream (SanMarco ${ }^{\circledR}$ ), hemp cheese, etc. Hemp seeds are also incorporated into pizza or used as salt substitute.
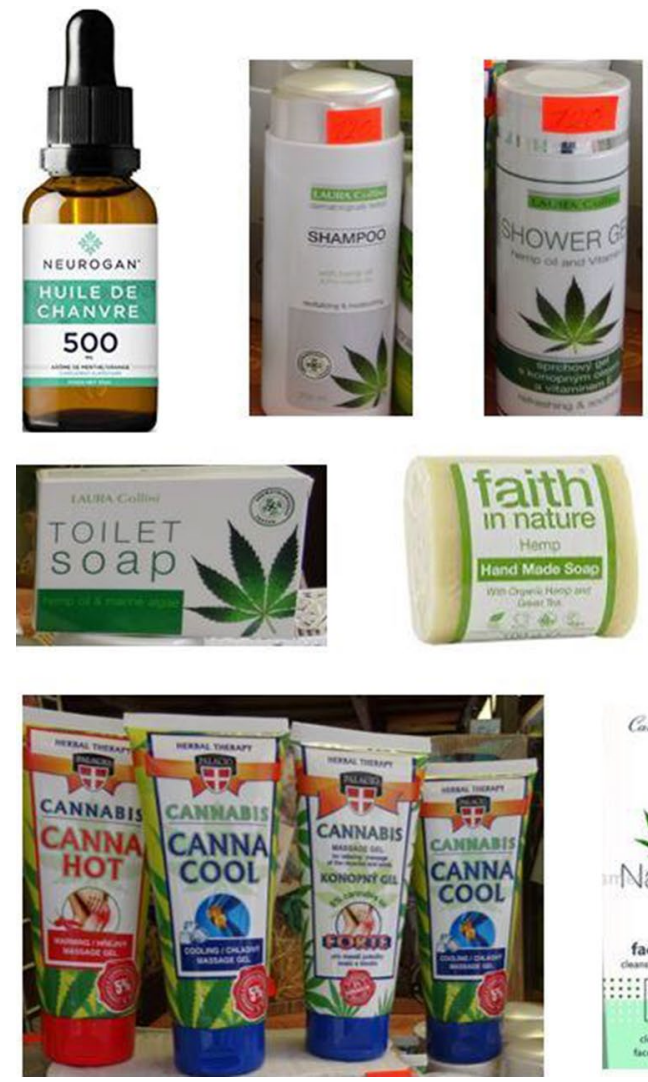
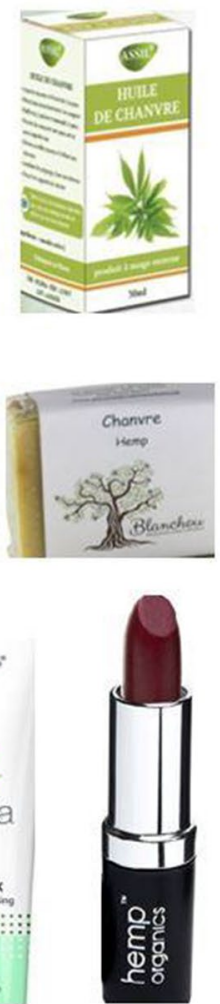
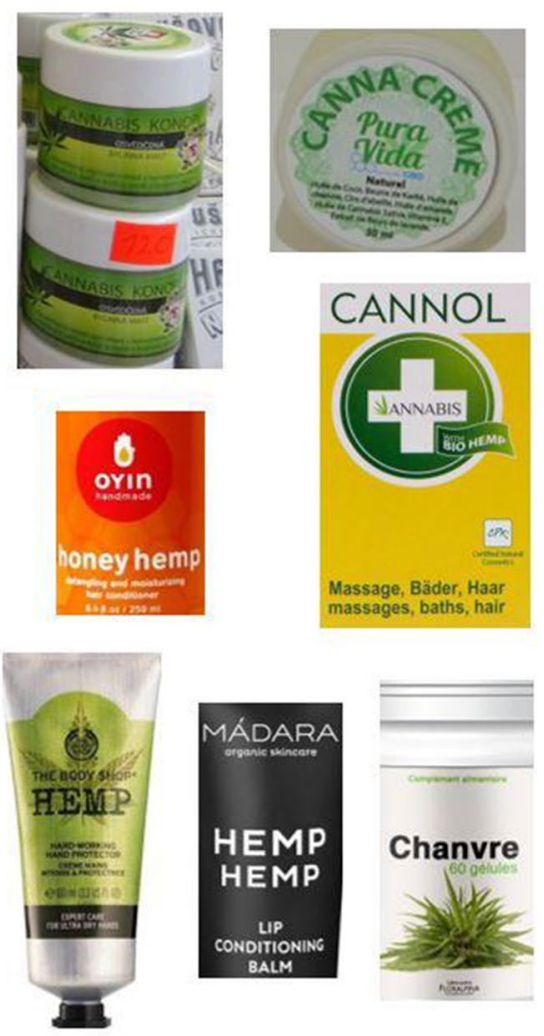

Fig. 8 Hemp-based cosmetics. Source: G. Crini, Chrono-environnement, Besançon, France 
Consumers are increasingly looking for products which are not only diverse in terms of taste, but also demonstrate improved nutritional properties, selecting foods with specific health-promoting properties (Fathordoobady et al. 2019; Mikulec et al. 2019; Leonard et al. 2020). Over the recent years, it has become very popular to enrich food products, including bread, with functional additives.

Mikulec et al. (2019) recently reported hemp flour as a valuable component for enriching physicochemical and antioxidant properties of wheat bread. The aim of their study was to use hemp flour for the production of bread and to determine their impact on selected chemical, texture, organoleptic characteristics, the color of the crumb, changes in the crumb texture, polyphenol profile, the total polyphenol and furan derivatives content. There is a lack of data regarding the influence of hemp flour on the antioxidant potential of bread nor the formation of furan derivates.

The results showed that bread with hemp flour was characterized by significantly higher protein content, in comparison with wheat bread. The share of 30 and $50 \%$ of hemp flour contributed to the reduction of organoleptic assessment of the bread. The hemp flour content significantly inhibited the changes in the hardness of bread crumb by reducing bread stalling index from 1.12 (wheat bread) to 0.05 (50\% of the additive). The share of hemp flour influenced the color of the crumb by increasing its browning index from 29.69 (standard bread) to 46.26 (50\% of the additive). The share of hemp flour influenced the polyphenols content and the formation of furan derivatives, e.g., furfuryl alcohol, furfuryl aldehyde and hydroxymethylfurfural, was dependent on the participation of hemp flour. For industrial production, the share of hemp flour should not exceed 30\% (Mikulec et al. 2019).

Hemp protein powder is brownish-green in color and has a taste that can be described as earthy or grassy for some, or nutty for others. It can have a grittier texture than other plant-based protein powders. So, it is best consumed blended with other ingredients (Small and Marcus 2002). For example, hemp powder is added to shakes or smoothies to boost protein intake. The cold-pressed hemp proteins are digestible. Protein powders containing essential amino acids, fibers, unsaturated fats, minerals, e.g., magnesium and iron, and antioxidants are popular nutritional supplements used by vegan persons, athletes, and bodybuilders to increase muscle mass (Bouloc 2013; Cherney and Small 2016; Fike 2016; Chandra et al. 2017; Johnson 2018).

However, there is a debate in the literature on the exact amount of the essential amino acids present in hemp protein powder and on their real impact. In addition, while hemp protein powder is safe for most people, there can be potential side effects, e.g., it can cause digestive problems. It is not recommended for pregnant or lactating women, and people with anemia or with allergies (Cherney and Small 2016; Chandra et al. 2017).

From a fundamental research point of view, there are a considerable effort to improve both nutritional and functional properties of hemp proteins through the exploitation of innovative processing conditions (Malomo et al. 2014; Malomo and Aluko 2015a, b; Korus et al. 2017; Pihlanto et al. 2017; Hadnađev et al. 2018; Dapčević-Hadnađev et al. 2019; Fathordoobady et al. 2019; King 2019; Wang and Xiong 2019; Zajac et al. 2019).

A technological challenge is the incorporation of hemp proteins, both as technological and biofunctional agents, into food products. Indeed, the utilization of these proteins in foods is limited because their behavior highly depends on their structure and composition, environmental factors, e.g., $\mathrm{pH}$, ionic strength, type of salt used, temperature, and isolation technique (Yin et al. 2008, 2009; Malomo and Aluko 2015a).

Various technologies have recently been proposed to improve the properties of hemp proteins, in particular gelling, foaming, and emulsifying properties, and antioxidant activity (Pihlanto et al. 2017; Hadnađev et al. 2018; Dapčević-Hadnađev et al. 2019; Zajac et al. (2019).

Zajac et al. (2019) recently reported that hemp products as valuable sources of nutrients, such as fatty acids, proteins and minerals, could be used to create functional meat products. This topic is interesting since the research on meat products containing hemp ingredients is limited. The authors compared the quality of pork loaves produced with the addition of hemp seeds (5\%), de-hulled hemp seeds (5\%), hemp flour (5\%), and hemp protein $(5 \%)$.

The results showed that addition of hemp ingredients increased the products' hardness and the fiber content. Magnesium, manganese, iron and copper content was also higher in the products with hemp. Polyunsaturated fatty acids content increased in products with de-hulled and whole hemp seeds. Oxidation is decreased in products with hemp ingredients containing hemp shell. There was no change in the microbial growth after the addition of all the tested ingredients.

The overall acceptability was lower for the products with hemp ingredients, but the taste of meat loaf with de-hulled hemp seeds was comparable with the control product. Zajac et al. (2019) concluded that the most promising ingredients in terms of improving the products' nutritional value were hemp seed and de-hulled hemp seed.

It was possible to create functional meat products using hemp ingredients, with the suggestion to make an optimal mixture, to increase the content of nutritional components without decreasing the consumers' acceptance. However, to encourage the consumers to consume hemp enriched meat products, the information about the healthy ingredients should be provided (Zajac et al. 2019). 
Although most research has focused on hemp seeds as a source of oils, proteins and essential fatty acids and minerals, recent studies also showed that that hemp inflorescences from fiber plants, i.e., hemp flowers and upper leaves, could be a good source of essential oils for flavoring in foods. However, the economic potential of these oils remains undefined (Fike 2016; Johnson 2018).

\section{Nutraceutical potential of hemp seeds and sprouts}

Hemp-based foods are gaining popularity, and the nutraceutical domain is developing fast due to several factors like the change of lifestyle, interest in alternative diets, and the increasing awareness about sustainable production of food.

Hemp seeds and oil are particularly interesting the nutraceutical domain because they are also an excellent source of protein, minerals, dietary fiber, essential fatty acids, amino acids, and other bioactive substances such as polyphenols. Polyphenols as antioxidants can protect the organism against free radicals attack by reducing or inhibiting cell damages due to the oxidation of lipids or other biomolecules (Conrad 1997; Hartsel et al. 2016; Frassinetti et al. 2018). However, the nutraceutical domain is in its infancy and needs to progress. In addition, food-grade hemp seed requires detailed functional characterization of component proteins (Malomo and Aluko 2015a).

Frassinetti et al. (2018) recently reported that seeds and sprouts of Cannabis sativa were rich in phytochemical compounds, particularly polyphenols such as caffeoyltyramine and cannabisin A, B, and C, and also in amino acids and saccharides. They possessed in vitro and ex vivo antioxidant activity, and also anti-mutagenic activity on yeast Saccharomyces cerevisiae. Due to the presence of bioactive compounds, seeds and sprouts can be used for nutraceutical and/ or therapeutic purposes.

The et al. (2016) and Girgih et al. (2014a) previously reported the antioxidant and antihypertensive properties of hemp seed peptides and protein hydrolysate. Werz et al. (2014) also suggested the use of hemp sprouts as a novel anti-inflammatory hemp food product finding that germination and sprouting processes induced the production of antiinflammatory compounds, prenylflavonoids cannflavins A and $\mathrm{B}$, while cannabinoids were not present at sprout stage.

The by-products of the oil production also contain secondary metabolites namely phenolic acids and flavonoids that have not been studied extensively. The and Birch (2014) showed that the application of ultrasound for optimization of yield of polyphenols from seed cakes contributed to industrial applications economically and environmentally since it reduced the usage of organic solvent and extraction time. The application of this technique was able to increase polyphenol extraction yields from cakes and aided in enhancing antioxidant capacity of the extracts.
The incorporation of heat during ultrasonic extraction resulted in higher polyphenol yields from the seed cakes compared to the ultrasonic treatment without heat. The polyphenols extracted from the seed cakes by ultrasonic treatment were a good source in product development for nutraceuticals and functional foods that could extend product shelf-life.

\section{Hemp and beverages}

In the last decade, plant-based foods and beverages are gaining popularity and the market is developing fast (ChalupaKrebzdak et al. 2018; Jeske et al. 2018; Jørgensen et al. 2019). For instance, there has been an expansion of milk alternative beverages originating from plant-based sources including soy, coconut, nuts, and hemp, e.g., Bjorg ${ }^{\circledR}$, Evernat ${ }^{\circledR}$ and Pacific ${ }^{\mathrm{TM}}$ Foods. The reasons for the emergence of market for milk substitutes of plant origin could be attributed to several factors such as cow's milk intolerance, e.g., lactose intolerance, cow's milk allergy, e.g., milk protein allergies, cultural reasons or diet choice, e.g., veganism, flexitarian diet, etc.

Among the various products on the market, hemp seed milk is a popular vegetable alternative to cow's milk, e.g., it is beneficial for people who are lactose intolerant or who avoid dairy products, soy or gluten (Small and Marcus 2002). It is also a good choice for those on a vegan diet. Hemp milk can easily be created at home by mixing water with the seed. This milk is rich in high-quality plant protein, healthy fats and minerals. The hemp-based milk alternative has a protein content of $0.83 \mathrm{~g} 100 \mathrm{~mL}^{-1}$. This hemp milk also contains alpha-linoleic acid, an essential omega-3 fatty acid, at $0.4 \mathrm{~g} 100 \mathrm{~mL}^{-1}$, i.e., $25 \%$ of recommended $1.6 \mathrm{~g} \mathrm{day}^{-1}$ intake (Chalupa-Krebzdak et al. 2018). Some commercial varieties are also fortified with vitamins and minerals.

Compared to whole cow's milk, hemp milk has fewer calories, less protein and carbs but roughly the same amount of fat. It has an earthy, nutty flavor and a creamy consistency. It can be used in place of cow's milk in smoothies, coffee or cereal. Indeed, due to its creamy consistency and protein content, hemp milk is excellent for making lattes, cappuccinos and other coffee drinks. A major concern people have about hemp milk is that it may contain THC as ingredient which is not the case from a regulatory point of view (Bouloc 2013; Jonaitiene et al. 2016; Chandra et al. 2017; Johnson 2018).

Hemp is steadily creeping into a wide range of beverage products (Fig. 7), e.g., protein shakes, infusions, hempinfused beers, e.g., Turn ${ }^{\circledR}$, Cannabia ${ }^{\circledR}$, Mandrin ${ }^{\circledR}$, Coors Light $^{\circledR}$, and Appenzeller Hanfblüte ${ }^{\mathrm{TM}}$, hemp-infused wines, hemp cocktails, e.g., Hempfy tonic gin, alcohols (hemp seed used as a flavorant), e.g., Hempfy Martini, lemonades, tea, 
e.g., HempTea, and coffee nog. Hemp seeds can also be used in a smoothie or a yogurt. All these products have a niche market, based on natural food and beverages, and specialty food outlets.

\section{Hemp for cosmetics and hygiene}

All the advantages associated with hemp give hemp seed oils a high market value and make their use likely not only in human food and nutritional supplements, but also in cosmetology and skin care (Fig. 8), aromatherapy, and medicine (Conrad 1997; Small and Marcus 2002; Bertoli et al. 2010; Kolodziejczyk et al. 2012; Ionescu et al. 2015; Ligeza et al. 2016; Bonini et al. 2018; Manosroi et al. 2019).

Hemp oil is indeed a good alternative to the chemicals present in many petroleum-based lotions and cosmetics. It is widely used in wellness and body care stores, e.g., for skin hydration, hand protector, hand sanitizer, body butter, body wash, etc. Its use is intended for people who are both sensitive to their well-being and to the protection of the environment. Consumers have a preference for natural ingredients with little or no impact on the environment.

In cosmetology, hemp is considered as a valuable resource for green cosmetics due to the high content of oil containing interesting substances for skin care with technological and therapeutic effects (Small and Marcus 2002; Vogl et al. 2004). In particular, hemp oils are interesting as natural ingredients/additives due to their high concentration of fatty acids, minerals and vitamins. Fatty acids are structural compounds of phospholipids in cell membranes that influence several cell membrane functions such as hormone activity.

Hemp oils and extracts have also captured a special attention due to their high antioxidant potential (Ionescu et al. 2015; Ligeza et al. 2016). Soothing and restructuring, natural cold-pressed oils can be applied to the skin, on the face and on the body (Conrad 1997). Thanks to its natural emollient and moisturizing properties, hemp oil is a common ingredient in body care products, e.g., soaps, shampoos, creams (SATIVA ${ }^{\mathrm{TM}}$, BodyShop ${ }^{\circledR}$ ), lotions, conditioners, and many other hair and beauty products, e.g., hair care, hair hydration and nourishment, scrubs, perfumes (Cannavis Santal Eau de Parfum), sunless bronzers (HEMPZ ${ }^{\circledR}$ ), lipstick (HempOrganics ${ }^{\mathrm{TM}}$ ), etc. The commercial products are paraben-free, THC-free, and 100\% vegan. Recent studies claim that oil reduces wrinkles and keeps the skin a youthful appearance (Ionescu et al. 2015; Ligeza et al. 2016).

The inflorescences of industrial hemp, obtained during cultivation, represent a consistent by-product that is underutilized. Its great availability makes it a potential additional resource to exploit and valorize at industrial level to produce niche products not only for food industry flavoring in foods, but also for cosmetics and pharmacy industry.

Indeed, hemp flowers and upper leaves contain essential oils that they can be used as a scent in perfumes, soaps and candles (Bertoli et al. 2010). These essential oils also have interesting antimicrobial and insecticidal activities (Górski et al. 2009). They can also be used in medicinal formulations (Fernandez-Ruiz et al. 2013). However, research on these topics is still poor (Benelli et al. 2018).

Cosmetic, functional foods and nutraceutical markets appear to be currently driving the hemp revival. However, products remain relatively expensive and their consumption is likely to be restricted.

\section{Hemp in medicine}

Just as hemp has been used for centuries for domestic and industrial purposes, hemp and cannabis/marijuana have been used for almost as long for medicinal purposes. Hemp seeds and its oil have been used to treat various disorders for thousands of years in traditional Asian medicine (Conrad 1997; de Padua et al. 1999; Leson 2013; Richard and Dejean 2013; Bonini et al. 2018). The medicinal properties of hemp have been exploited since $5000 \mathrm{BC}$ in China and India, e.g., for a number of indications including fever, rheumatic pains, menstrual pains and constipation. The Ancient Greeks and Romans also used cannabis roots for medicinal purposes. For a historical review of this topic, see Russo (2007) and Hanus (2009).

As we have already said, hemp/industrial hemp and marijuana/medical cannabis are often confused (Holler et al. 2008; Sawler et al. 2015; VanDolah et al. 2019). However, hemp and marijuana are different varieties of the plant $\mathrm{Can}$ nabis sativa L., the first being grown for seeds, oil, fiber and therapeutic hemp, the second for its high content of the psychoactive substance tetrahydrocannabinol (cannabidiol oils).

Industrial hemp versus therapeutic hemp? Hemp is grown differently than marijuana, and the extract is obtained from specific parts of the plant which do not contain tetrahydrocannabinol. Most of the tetrahydrocannabinol content is found in the buds and flowers of the cannabis plant, but industrial hemp is not cultivated to produce buds, so this explains the different content of tetrahydrocannabinol in marijuana versus hemp.

What is therapeutic hemp? This term refers to strains of cannabis that do not contain enough tetrahydrocannabinol to render a psychoactive reaction when ingested by the user. Therapeutic hemp is used to make cannabis concentrate oils that are high in cannabidiol rather than tetrahydrocannabinol. The oil derived from therapeutic hemp is commonly referred to as cannabidiol hemp oil. Charlotte's Web Medical 
Hemp Act defines therapeutic hemp as "hemp that doesn't make you high."

VanDolah et al. (2019) recently summarized the current legal status of cannabidiol and hemp oils in the USA and provided a guide to identifying higher-quality products so that clinicians could advise their patients on the safest and most evidence-based formulations.

Hemp seeds are a good source of cannabidiol, but special extraction techniques are required for its production. From the 1970s, the pharmaceutical industry developed various cannabinoid-based formulations, e.g., Cesamet $\odot$, a synthetic derivative of tetrahydrocannabinol used to treat vomiting and nausea and against neurological pain (Small and Marcus 2002), Marinol@ also used in the treatment of nausea and vomiting and it can stimulate the appetite of cachectic AIDS patients (Richard and Dejean 2013).

Essential oils containing cannabinoids are approved and marketed, e.g., Sativex ${ }^{\circledR}$ Nabiximol as adjunctive treatment for symptomatic relief of spasticity in adult patients. These products are indicated for the treatment of multiple sclerosis, epilepsy and side effects of cancer chemotherapy. In 2018, the first cannabidiol-based drug, Epidiolex ${ }^{\circledR}$, was approved by the US Food and Drug Administration for treatment of rare, severe epilepsy, further putting the spotlight on cannabidiol and hemp oils (VanDolah et al. 2019).

Currently, in China, hemp is widely used as a component not only for food but also for medicine: medicines that heal wounds, temper chronic pain, rheumatic pains, menstrual pains and nausea, reduces seizures in epileptics, to reduce acne breakouts and improve skin conditions, to treat dermatitis and eczema, etc.

There are other benefits attributed to compounds derived from various parts of the hemp plant, particularly seed due to its polyunsaturated fatty acids and cannabidiol content, such as anticancer, anti-inflammatory and anti-thrombosis properties, stimulation of general metabolism, neuroprotective effect, promotion of fat burning, hypertension and oxidative stress treatments, help to regulate the immune system, and inflammatory bowel disease (Rodriguez-Leyva and Pierce 2010; Cassano et al. 2013; Russo and Reggiani 2013; Girgih et al. 2014a, b; Cherney and Small 2016; Hartsel et al. 2016; Parian and Limketkai 2016; Pathak et al. 2016; Bonini et al. 2018; Zhou et al. 2018; Devi and Khanam 2019a; Fathordoobady et al. 2019; Fiorini et al. 2019; Mamone et al. 2019).

Some research has suggested that hemp seeds could protect the brain, e.g., positive effects in Parkinson's disease, Alzheimer's disease, and multiple sclerosis (Sative ${ }^{\circledR}$ is approved in Canada), boost heart health, e.g., reduce the risk of arrhythmias, reduce inflammation (type 2 diabetes), relieve rheumatoid arthritis, and improve skin conditions, e.g., reduce acne symptoms (Rodriguez-Leyva and Pierce 2010; Cassano et al. 2013; Russo and Reggiani 2013; Girgih et al. 2014a, b; Cherney and Small 2016; Hartsel et al. 2016; Parian and Limketkai 2016; Pathak et al. 2016; Bonini et al. 2018; Zhou et al. 2018; Devi and Khanam 2019a; Fathordoobady et al. 2019; Fiorini et al. 2019; Mamone et al. 2019).

However, although the properties and virtues of hemp have been recorded for several thousand years, their medical applications are still not universally recognized and continue to stir much controversy (Fike 2016; Żuk-Gołaszewska and Gołaszewski 2018). Much work is needed to verify various claims about hemp's efficacy.

As reported by Fike (2016) "excitement over this potential needs to be cautious because data in the literature regarding hemp's nutritional and medicinal benefits are somewhat limited and variable, and much of the work has been conducted with animal models." Indeed, great care must be continually taken when reading information on therapeutic hemp and wellness.

\section{Essential oils from hemp as an effective tool for insect pest management}

Hemp flowers and upper leaves, considered as low-cost by-products, contain essential oils that they can be used as flavoring in foods or as a scent in cosmetics (Thoma et al. 2000; Small and Marcus 2002). Interestingly, these oils have also been shown to be toxic to mosquitoes larvae (Thoma et al. 2000). Other valuable properties often cited are their antimicrobial (Verma et al. 2014) and nematicidal (Mukhtar et al. 2013) properties. Thus, by-products of industrial hemp could also represent an exploitable material to produce biopesticides for agrochemistry sector.

The use of hemp in agrochemistry seems to be a promising field as reported in various studies (Mukhtar et al. 2013; Isman 2015; Bedini et al. 2016; Pavela and Benelli 2016; Abé et al. 2018; Benelli et al. 2018; Fiorini et al. 2019; Salentijn et al. 2019). The following example is interesting.

The Asian tiger mosquito Aedes albopictus is acknowledged as the most invasive mosquito species worldwide. Because of its aggressive daytime human-biting behavior and its ability to transmit many pathogens and parasites, including dengue yellow fever and chikungunya, it represents a key threat for millions of people worldwide. The freshwater pan-pulmonate snail Physella acuta is another problematic invasive species that shares the same habitats of the Aedes albopictus larvae, and it is considered a plague in rice fields. Nowadays, pests are largely controlled by synthetic pesticides. However, the continuous use of organophosphates and insect growth regulators has caused the rising of resistant mosquito strains. Besides, currently employed molluscicides are limited in number, expensive and also have negative effects on human health 
and the environment. Thus, there is a growing interest for alternative eco-friendly control tools for pest management.

The potential of essential oil from industrial hemp as an environmental-friendly botanical insecticide was studied by Bedini et al. (2016). These authors reported that this essential oil was effective against larvae of mosquito vectors and moth pests, as well as against flies and snails. They concluded that hemp essential oils represented new low-cost environmentally friendly insecticides and molluscicides. In addition, these oils are interesting because they are characterized by low toxicity toward other nontarget organisms.

Another recent work has been published by the same group (Benelli et al. 2018). The authors used an essential oil obtained by fresh inflorescences of hemp, monoecious $c v$. Felina 32 by steam-distillation. Its composition, analyzed by gas chromatography and gas chromatography-mass spectrometry, was dominated by monoterpene and sesquiterpene hydrocarbons, with $(E)$-caryophyllene (45.4\%), myrcene $(25.0 \%)$ and $\alpha$-pinene $(17.9 \%)$ as the most abundant derivatives. The oil was tested against the filariasis vector Culex quinquefasciatus, the peach-potato aphid Myzus persicae, the housefly Musca domestica and the tobacco cutworm Spodoptera littoralis. To prove its harmlessness on non-target invertebrates, it was also tested on the multicolored Asian lady beetle, Harmonia axyridis, and Eisenia fetida earthworms, and compared with $\alpha$-cypermethrin as the positive control.

Results from insecticidal tests showed that the essential oil from inflorescences of industrial hemp $c v$. Felina 32 was highly toxic to Myzus persicae aphids (LC50 of $3.5 \mathrm{~mL} \mathrm{~L}^{-1}$ ) and Musca domestica flies (43.3 $\mu \mathrm{g}^{\text {adult }}{ }^{-1}$ ), while toxicity was moderate toward Spodoptera littoralis larvae (152.3 $\left.\mu \mathrm{g} \mathrm{larva}^{-1}\right)$, and scarce against Culex quinquefasciatus larvae (LC50 of $252.5 \mathrm{~mL} \mathrm{~L}^{-1}$ ) and adults (LC50 $>500 \mu \mathrm{g} \mathrm{cm}^{-2}$ ). Contrary to $\alpha$-cypermethrin, the hemp $c v$. Felina 32 essential oil was not toxic to nontarget invertebrate species, including 3rd instar larvae and adults of Harmonia axyridis ladybugs and adults of Eisenia fetida earthworms. The authors concluded that the essential oil from industrial hemp by-products is an effective tool for insect pest management in organic crops, particularly to manage aphid and housefly populations (Benelli et al. 2018). The chemical characterization is a crucial step before any kind of biological assay.

Abé et al. (2018) also reported the insecticidal activity of Cannabis sativa L. leaf essential oil on the malaria vector Anopheles gambiae s.l. larvae. Their work showed high insecticidal effect of this oil against both larvae and adult after $24 \mathrm{~h}$ of exposition in controlled conditions. The authors concluded that Cannabis sativa L. leaf essential oil could be a serious alternative to insecticides. Further studies are required to assess the same effect in the environment.

\section{New uses for hemp for energy production}

Industrial hemp is an attractive biomass not only for bioplastic production but also for energy production. Indeed, biomass conversion to biofuels and bioproducts has generated in the last three decades a lot of interest due to the increasing demand for producing a sustainable energy supply that can be incorporated to the existing fuel system.

Traditionally, biofuels have been produced based on starches or sugars such as wheat, corn, sugar beets and sugarcane. New opportunities to use hemp biomass as solid fuel or feedstock in biogas and bioethanol production have been reported. A number of claims have been made that hemp could be used in energy production, as a fuel source with no sulfur emissions, either burnt directly or converted into liquid fuels such as bioethanol (Burczyk et al. 2008; Rice 2008; Li et al. 2010; Sipos et al. 2010; Ahmad et al. 2011; Kreuger et al. 2011; Prade et al. 2011, 2012; Gomes 2012; Finnan and Styles 2013; Rehman et al. 2013; Kuglarz et al. 2014, 2016; Fernando et al. 2015; Das et al. 2017; Schluttenhofer and Yuan 2017; Asquer et al. 2019).

Industrial hemp is valuable due to its high biomass and energy yields per hectare. For centuries, hemp oil was used as lamp oil. Today, hemp oil can be used to create biofuels to replace gasoline for diesel engines without any needed modifications. These biofuels are renewable and produce less of greenhouse gas carbon monoxide, potentially helping relieve global warming.

Figure 9 shows the possible pathway of bioenergy production from industrial hemp biomass (Rehman et al. 2013). This annual plant can be used to produce different products in a biorefinery concept which includes production of vehicle fuels, e.g., biogas from anaerobic digestion or bioethanol from fermentation, heat from briquettes or pellets, electricity from baled biomass, feed and biochemical such as succinic acid. Advantages over other energy crops are also found outside the energy balance, e.g., low pesticide requirements, good weed competition and in crop rotations (annual cultivation). The main competitors for hemp are maize and sugar beets for biogas production and the perennial crops willow, reed canary grass and miscanthus for solid biofuel production (Prade et al. 2012; Asquer et al. 2019).

Hemp can provide two types of fuels/biofuels, biodiesel made from the oil of the pressed seed and bioethanol and methanol made from the fermented stalk. Biodiesel is considered as a clean and renewable energy alternative to petroleum-based diesel fuel. Bioethanol is also considered as one of the most promising biofuels as it can be easily incorporated into existing fuel systems and can partially substitute fossil fuels used in transportation. However, the 


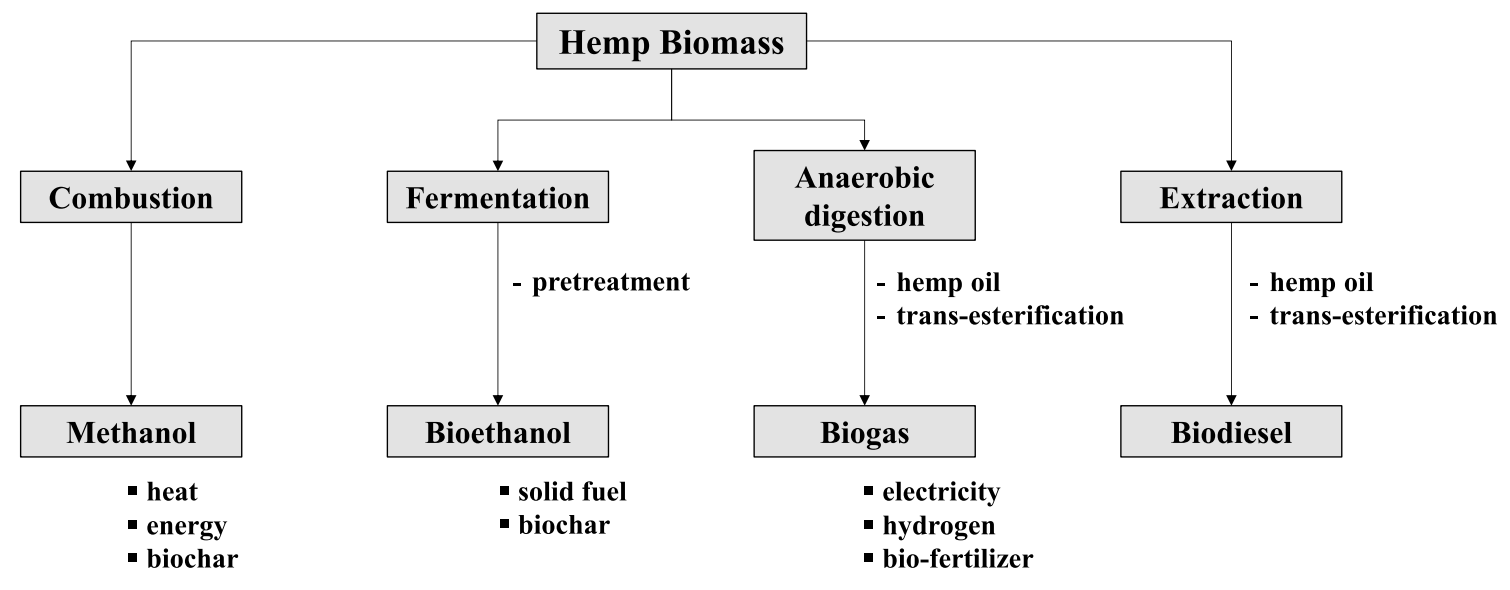

Fig. 9 Bioenergy pathways of hemp biomass conversion. Adapted from Rehman et al. (2013)

most important problem is to understand whether industrial hemp can yield biofuel quantities comparable to the other biomass feedstocks. Another problem is the development of efficient pretreatment technologies to remove lignin and facilitate enzyme access to the cellulose for sugar release.

Angelidaki's group demonstrated that industrial hemp can be used for cellulosic bioethanol and succinic acid production in a biorefinery concept (Kuglarz et al. 2014, 2016). Two types of pretreatments, i.e., dilute-acid treatment and alkaline oxidative method, were studied. The results showed that high cellulose recovery $(>95 \%)$ as well as significant hemicelluloses solubilization (49-59\%) after acid-based method and lignin solubilization (35-41\%) after alkaline $\mathrm{H}_{2} \mathrm{O}_{2}$ method were obtained. The highest ethanol production was achieved after hemp pretreatment by alkaline oxidative method (Kuglarz et al. 2016). However, acid-based pretreatment of hemp was superior to alkaline oxidative method with respect to the combined ethanol and succinic acid production.

The mass balance calculations showed that $149 \mathrm{~kg}$ of bioethanol and $115 \mathrm{~kg}$ of succinic acid can be obtained per 1 ton of dry hemp. Taking into account the costs of biomass processing, from field to ethanol facility storage, the field-dried hemp pretreated at the optimal conditions showed positive economic results. Angelidaki's group previously showed that the type of hemp cultivation, i.e., organic or conventional, did not influence significantly the effectiveness of the pretreatment as well as subsequent enzymatic hydrolysis and ethanol fermentation (Kuglarz et al. 2014).

Das et al. (2017), using a combined agronomic, experimental and economic analysis approach, reported that industrial hemp is a potential bioenergy crop in comparison with kenaf, switchgrass and biomass sorghum. For instance, the authors reported a predicted ethanol yield of 82 gallons/dry ton hemp stems which was comparable to the other three tested feedstocks. However, despite numerous studies related to the biofuels potential of hemp, its technical and economic feasibility still remains unclear (Fike 2016; Johnson 2018).

\section{Environmental applications}

One of the most interesting applications for hemp is in cleaning up soil contamination through phytoremediation and phytoextraction processes. Hemp has been tested with favorable results as phytoextractor in areas where lands were contaminated with various pollutants such as metals, radioactive elements, organics including pesticides and fertilizers, oils and solvents (Linger et al. 2002; Small and Marcus 2002; Citterio et al. 2003; Vandenhove and Van Hees 2003; Gomes 2012; Gupta et al. 2013; Ahmad et al. 2016; Kostić et al. 2018; Morin-Crini et al. 2018; Bai et al. 2020a, b; Saxena et al. 2020).

Linger et al. (2002) previously reported that hemp was able to decontaminate metal polluted soils. All parts of plants, i.e., seeds, leaves, fibers and hurds, contained metals but the metal accumulation in these different parts was extremely different. The highest concentrations of $\mathrm{Ni}, \mathrm{Pb}$ and $\mathrm{Cd}$ were accumulated in the leaves. In the field trial, hemp demonstrated a phytoextraction potential of $126 \mathrm{~g} \mathrm{Cd}$ (ha vegetation period) ${ }^{-1}$. The authors showed that the high quality of the fibers and hurds, which were not affected by the metal contamination, allowed them to be used in special products like combine material (Linger et al. 2002).

Hemp plants were shown to be effective in cleaning the soil around the site of Russia's Chernobyl nuclear disaster (Vandenhove and Van Hees 2003). They were also considered for use near Fukushima (Morin-Crini et al. 2018).

Another interesting environmental field is the removal of pollutants present in aqueous solution by hemp-based biosorbents. Indeed, with the increasing focus on renewable 
materials and sustainability issues, the development of nonconventional materials from natural resources and possessing complexing and chelating properties such as hemp is currently an area of extensive research due to their potential applications in pollutant removal, e.g., in water and wastewater treatment.

This is an interesting challenge because the majority of commercial organic resins are derived from petroleum-based raw materials using processing chemistry that is not always safe or environmental friendly. Today, there is growing interest in developing natural low-cost alternatives to synthetic resins and polymers. Hemp as biosorbent could be a promising alternative.

In the last decade, several research groups published numerous works on the ability of hemp to act as an effective biosorbent for the removal of metals from aqueous solutions or industrial effluents (Kostić et al. 2008, 2010; Pejić et al. 2008, 2009, 2011; Rosas et al. 2009; Tofan et al. 2009, 2010a, b, c, 2013, 2015, 2016a, b; Zou et al. 2012; Vukčević et al. 2012, 2014a, b, 2015; Yang et al. 2011, 2012; Rezić 2013; Sun et al. 2013; Balintova et al. 2014; Lupul et al. 2015a, b; Kyzas et al. 2015; Wang et al. 2015; Bugnet et al. 2017a, b; Loiacono et al. 2017a, b, c, 2018a, b; Morin-Crini et al. 2018, 2019).

Many materials containing hemp in raw, modified or carbon forms, have been proposed. All these results clearly demonstrated that hemp had a high affinity for metals such as $\mathrm{Cd}, \mathrm{Co}, \mathrm{Cr}, \mathrm{Cu}, \mathrm{Mn}, \mathrm{Ni}, \mathrm{Pb}$ and $\mathrm{Zn}$. Hemp is able to remove metals from mono- and polycontaminated solutions and the performances are in general almost independent of $\mathrm{pH}$ between 4 and 6 . Strong bonding of metal ions by carboxylic present in hemicelluloses, pectin and lignin, phenolic (lignin and extractives), carbonyl (lignin) and hydroxyl (polysaccharides) groups are responsible of the adsorption through chemisorption. However, the performance depends on the hemp form used, i.e., fibers, shives or felt, and also on the residual concentration of the metal in solution. In addition, all the works are in the stage of laboratory-scale study using often standard solutions containing one or a few metals. Future research needs to demonstrate the possibilities on an industrial scale using real polycontaminated wastewaters and discharge waters (Morin-Crini et al. 2018, 2019).

\section{Miscellaneous applications}

Other domains for hemp uses include paints, e.g., ChanvreMat, Milk Paint, varnishes, ink and lubricants, solvents, detergents, and industrial cleaners (Small and Marcus 2002; Callaway 2004; Bouloc 2013).

Innovative applications such as coatings, nanotechnology, e.g., nanomaterials with similar properties as graphene, supercapacitors (TitanHemp) and nanosheets, hemp plastic for
3D printing (Kanesis $\mathrm{HBP}^{\circledR}$ ), biocomposites for airplanes or solar panels, in cleaning up air, acoustic domain and biotechnologies opens new challenges (Chauhan et al. 2019; Khattab and Dahman 2019; Kumar et al. 2019; Rossi et al. 2020). For instance, hemp-based supercapacitors offer an affordable next-generation energy source to replace rechargeable batteries for applications such as electric cars, power tools and mobile devices (Sun et al. 2016). Several patents have been filed in recent years.

\section{Conclusion}

Industrial hemp is commonly used to refer to Cannabis strains cultivated for industrial use, i.e., for non-drug use. Although industrial hemp is a niche crop (Food and Agriculture Organization of the United Nations, www.faostat.fao.org), its production is currently experiencing a renaissance, particularly in Europe and North America. China is the largest producer and exporter of hemp in the world. Hemp is a valuable crop for the bio-based economy because of its unique properties and environmental benefits, and the high yield of natural products it provides.

Hemp is a multi-purpose crop delivering stalks, seeds and leaves, which find numerous applications. Its uses are indeed manifold: construction materials, textiles, paper, food and beverages, automotive sector, furniture, luxury market, cosmetics and personal care items, etc. There are an estimated 25,000 products derived from industrial hemp. The importance of functional foods and nutraceuticals containing hemp products is related to health promotion and diseases risk reduction. Neutraceutical products, cosmeceuticals, medical and therapeutic domains should be the next market in the development of industrial hemp. Other potential uses and innovative applications opens new challenges, e.g., phytoremediation, wastewater treatment, energy production, biofuels, bio-based plastics, and biopesticides.

The economics of the use of hemp products are a subject of ongoing debate, research and development, and trade analysis (Fike 2016). Although these available economic data are still limited, the hemp industry continues to evolve and invest (source: BDS Analytics Newsletter, 2019). Whether the hemp industry will grow depends on the political and economic framework in the European Union and other countries such as Canada and the USA. The future development of hemp will also depend strongly on market demand for green products that are both beneficial to human health and have no impact on the environment.

\section{References}

Abé H, Foko Dadji AF, Nkondjio CA, Awono-Ambene PH, Tamesse JL (2018) Insecticidal activity of Cannabis sativa L. leaf essential 
oil on the malaria vector Anopheles gambiae s.l (Giles). Int $\mathbf{J}$ Mosq Res 5:65-74

Ahmad M, Ullah K, Khan MA, Zafar M, Tariq M, Ali S, Sultana S (2011) Physicochemical analysis of hemp oil biodiesel: a promising non edible new source for bioenergy. Energy Sources A Recovery Util Environ Effects 33:1365-1374. https://doi. org/10.1080/15567036.2010.499420

Ahmad R, Tehsin Z, Malik ST, Asad SA, Shahzad M, Bilal M, Shah MM, Khan SA (2016) Phytoremediation potential of hemp (Cannabis sativa $\mathrm{L}$.): identification and characterization of heavy metals responsive genes. CLEAN Soil Air Water 44:195-201. https ://doi.org/10.1002/clen.201500117

Aït Oumeziane Y, Moissette S, Bart M, Lanos C (2016) Influence of temperature on sorption process in hemp concrete. Constr Build Mater 106:600-607. https://doi.org/10.1016/j.conbuildma t.2015.12.117

Allegret S (2013) The history of hemp. In: Bouloc P, Allegret S, Arnaud L (eds) Hemp-industrial production and uses. CAB International, Wallingford

Amaducci S (2005) Hemp production in Italy. J Ind Hemp 10:109-115

Amaducci S, Gusovious HJ (2010) Hemp-cultivation, extraction and processing. In: Müssig J (ed) Industrial applications of natural fibres: structure, properties and technical applications. Willey, Chichester, pp 109-135. https://doi.org/10.1002/9780470660 324.ch5

Amziane S, Arnaud L (2013) Bio-aggregate-based building materials: applications to hemp concretes. Wiley, Hoboken. ISBN 978-1-84821-404-0

Andre CM, Hausman JF, Guerriero G (2016) Cannabis sativa: the plant of the thousand and one molecules. Front Plant Sci 7:1-17. https ://doi.org/10.3389/fpls.2016.00019

Arizzi A, Viles H, Martin-Sanchez I, Cultrone G (2016) Predicting the long-term durability of hemp-lime renders in inland and coastal areas using Mediterranean, tropical and semi-arid climatic simulations. Sci Total Environ 542:757-770. https://doi. org/10.1016/j.scitotenv.2015.10.141

Arnaud L, Gourlay E (2012) Experimental study of parameters influencing mechanical properties of hemp concretes. Constr Build Mater 28:50-56. https://doi.org/10.1016/j.conbuildma t.2011.07.052

Asquer C, Melis E, Scano EA, Carboni G (2019) Opportunities for green energy through emerging crops: biogas valorization of Cannabis sativa L. residues. Climate 7:142. https://doi. org/10.3390/cli7120142

Bai Z, Liu Q, Zhang H, Liu J, Yu J, Wang J (2020a) A novel 3D reticular anti-fouling bio-adsorbent for uranium extraction from seawater: polyethylenimine and guanidyl functionalized hemp fibers. Chem Eng J 382:122555. https://doi.org/10.1016/j. cej.2019.122555

Bai Z, Liu Q, Zhang H, Liu J, Yu J, Wang J (2020b) High efficiency biosorption of uranium (VI) ions from solution by using hemp fibers functionalized with imidazole-4-5-dicarboxylic. J Mol Liq 297:111739. https://doi.org/10.1016/j.molliq.2019.111739

Bajpai P (2018) Biotechnology for pulp and paper processing. Springer, Singapore, pp 1-588. ISBN 978-981-10-7853-8

Balintova M, Holub M, Stevulova N, Cigasova J, Tesarcikova M (2014) Sorption in acidic environment-biosorbents in comparison with commercial adsorbents. Chem Eng Trans 39:625-630. https:// doi.org/10.3303/CET1439105

Barberà L, Pèlach MA, Pérez I, Puig J, Mutjé (2011) Upgrading of hemp core for papermaking purposes by means of organosolv process. Ind Crops Prod 34:865-872. https://doi.org/10.1016/j. indcrop.2011.02.005

Bedini S, Flamini G, Cosci F, Ascrizzi R, Benelli G, Conti B (2016) Cannabis sativa L. and Humulus iupulus essential oils as novel control tools against the invasive mosquito Aedes albopictus and fresh water snail Physella acuta. Ind Crops Prod 85:318-323. https://doi.org/10.1016/j.indcrop.2016.03.008

Benelli G, Pavela R, Petrelli R, Cappellacci L, Santini G, Fiorini D, Sut S, Dall'Acqua S, Canale A, Maggi F (2018) The essential oil from industrial hemp (Cannabis sativa L.) by-products as an effective tool for insect pest management in organic crops. Ind Crops Prod 122:308-315. https://doi.org/10.1016/j.inder op.2018.05.032

Bertoli A, Tozzi S, Pistelli L, Angelini LG (2010) Fibre hemp inflorescences: from crop-residues to essential oil production. Ind Crops Prod 32:329-337. https://doi.org/10.1016/j.indcrop.2010.05.012

Bhavani K (2015) Performance evaluation of various natural agro fibres in carpet making and their costing. Asian J Home Sci 10:296300. https://doi.org/10.15740/HAS/AJHS/10.2/296-300

Bócsa L, Karus M (1998) The cultivation of hemp: botany, varieties, cultivation and harvesting. Hemptech, Sebastopol, p 184. ISBN 978-1-886874-03-9

Bonini SA, Premoli M, Tambaro S, Kumar A, Maccarinelli G, Memo M, Mastinu A (2018) Cannabis sativa: a comprehensive ethnopharmacological review of a medicinal plant with a long history. J Ethnopharm 227:300-315. https://doi.org/10.1016/j. jep.2018.09.004

Bono P, le Duc A, Lozachmeur M, Day A (2015) Materials: new fields of research and development for the valorization of technical plant fibres (flax fiber and hemp). OCL oilseeds and fats crops and lipids. EDP Sciences 22:1-11. https://doi.org/10.1051/ ocl/2015041

Bouloc P (2013) Hemp: industrial production and uses. CABI, Oxfordshire, p 312. ISBN 978-1-845-93793-5

Bran M, Olaru S, Dobre I (2017) Flax, hemp and cotton plants in Romania - a study for reconsideration of the textile industry. Ind Textila 68:186-192

Bugnet J, Morin-Crini N, Cosentino C, Chanet G, Winterton P, Crini G (2017a) Hemp decontamination of poly-metallic aqueous solutions. Environ Eng Manag J 16:535-542

Bugnet J, Morin-Crini N, Chanet G, Cosentino C, Crini G (2017b) Du chanvre pour dépolluer des eaux polycontaminées en métaux. In: Morin-Crini G, Crini G (eds) Chapter XI. PUFC, Besançon, pp 323-340

Burczyk H, Grabowska L, Kołodziej J, Strybe M (2008) Industrial hemp as a raw material for energy production. J Ind Hemp 13:37-48. https://doi.org/10.1080/15377880801898717

Callaway JC (2004) Hemp seed as a nutritional resource: an overview. Euphytica 140:65-72. https://doi.org/10.1007/s1068 1-004-4811-6

Cassano R, Trombino S, Ferrarelli T, Nicoletta FP, Mauro MV, Giraldi C, Picci N (2013) Hemp fiber (Cannabis sativa L.) derivatives with antibacterial and chelating properties. Cellulose 20:547557. https://doi.org/10.1007/s10570-012-9804-3

Chalupa-Krebzdak S, Long CJ, Bohrer BM (2018) Nutrient density and nutritional value of milk and plant-based milk alternatives. Int Dairy J 87:84-92. https://doi.org/10.1016/jdairyl.2018.07.018

Chandra S, Lata H, Elsohly MA (eds) (2017) Cannabis sativa L.- - botany and biotechnology. Springer, Cham. ISBN 978-3-319-54563-9

Chauhan V, Karki T, Varis J (2019) Review of natural fiber-reinforced engineering plastic composites, their applications in the transportation sector and processing techniques. J Thermoplast Compos Mater UNSP. https://doi.org/10.1177/0892705719889095

Cherney JH, Small E (2016) Industrial hemp in North America: production, politics and potential. Agronomy 6:1-24. https://doi. org/10.3390/agronomy6040058

Chernova T, Mikshina P, Salnikov V, Ageeva M, Ibragimova N, Sautkina O, Gorshlova T (2018) Development of hemp fibers: the key components of hemp plastic composites. IntechOpen 3:41-56. https://doi.org/10.5772/intechopen.70976 
Cigasova J, Stevulova N, Schwarzova I, Sicakova A, Junak J (2015) Application of hemp hurds in the preparation of biocomposites. In: IMST 2015, IOP conference series materials science and engineering. vol. 96, pp 012023

Citterio S, Santagostino A, Fumagalli P, Prato N, Ranalli P, Sgorbati S (2003) Heavy metal tolerance and accumulation of $\mathrm{Cd}, \mathrm{Cr}$ and Ni by Cannabis sativa L. Plant Soil 256:243-252. https://doi. org/10.1023/A:1026113905129

Collet F, Chamoin J, Pretot S, Lanos C (2013) Comparison of the hygric behaviour of three hemp concretes. Energy Build 62:294-303. https://doi.org/10.1016/j.enbuild.2013.03.010

Conrad C (1997) Hemp for health: the medicinal and nutritional uses of Cannabis sativa. Healing Arts Press, Rochester. ISBN 0-89281-539-6

Crini G, Lichtfouse E, Chanet G, Morin-Crini N (2020) Traditional and new applications of hemp. In: Crini G, Lichtfouse E (eds) Hemp production and applications, vol 42. Sustainable agriculture reviews. Springer, Cham

Danielewicz D, Surma-Slusarska B (2017) Properties and fibre characterization of bleached hemp, birch and pine pulps: a comparison. Cellulose 24:5173-5186. https://doi.org/10.1007/s1057 0-017-1476-6

Dapčević-Hadnađev T, Hadnađev M, Lazaridou A, Moschakis T, Biliaderis CG (2019) Hempseed meal protein isolates prepared by different isolation techniques. Part II. Gelation properties at different ionic strengths. Food Hydrocoll 81:481-489. https://doi. org/10.1016/j.foodhyd.2018.03.022

Das L, Liu E, Saeed A, Williams DW, Hu H, Li C, Ray AE, Shi J (2017) Industrial hemp as a potential bioenergy crop in comparison with kenaf, switchgrass and biomass sorghum. Bioresour Technol 244:641-649. https://doi.org/10.1016/j.biort ech.2017.08.008

De Candolle A (1883) Origine des plantes cultivées. Librairie Germer Baillière et Cie, Paris. ISBN 2-734-80142-6

de Padua LS, Bunyaprafatsara N, Lemmens RHMJ (eds) (1999) Plant resources of south-east Asia: medicinal and poisonous plants, vol 1. Backhuys Publishers, Leiden, pp 167-175

Devi V, Khanam S (2019a) Comparative study of different extraction processes for hemp (Cannabis sativa) seed oil considering physical, chemical and industrial-scale economic aspects. J Clean Prod 207:645-657. https://doi.org/10.1016/j.jclepro.2018.10.036

Devi V, Khanam S (2019b) Study of $\omega-6$ linoleic and $\omega-3 \alpha$-linoleic acids of hemp (Cannabis sativa) seed oil extracted by supercritical $\mathrm{CO}_{2}$ extraction: CCD optimization. J Environ Chem Eng 7:102818. https://doi.org/10.1016/j.jece.2018.102818

Dubois S, Evrard A, Lebeau F (2014) Modeling the hygrothermal behavior of biobased construction materials. J Build Phys 38:191-213. https://doi.org/10.1177/1744259113489810

Dunford NT (2015) Hemp and flaxseed oil: properties and applications for use in food. In: Talbot G (ed) Specialty oils and fats in food and nutrition: properties, processing and applications. Elsevier, Amsterdam, pp 39-63. https://doi.org/10.1016/B978-1-78242 $-376-8.00002-8$

Elfordy S, Lucas F, Tancret F, Scudeller Y, Goudet L (2008) Mechanical and thermal properties of lime and hemp concrete (hempcrete) manufactured by a projection process. Constr Build Mater 22:2116-2123. https://doi.org/10.1016/j.conbuildma t.2007.07.016

Fangueiro R, Rana S (eds) (2016) Natural fibers: advances in science and technology toward industrial applications. From science to market. Springer, Berlin. https://doi. org/10.1007/978-94-017-7515-1

Faruk O, Bledzki A, Fink HP, Sain M (2012) Biocomposites reinforced with natural fibers: 2000-2010. Prog Polym Sci 37:1552-1596. https://doi.org/10.1016/j.progpolymsci.2012.04.003
Fathordoobady F, Singh A, Kitts DD, Singh AP (2019) Hemp (Cannabis sativa L.) extract: anti-microbial properties, methods of extraction, and potential oral delivery. Food Rev Int 35:664-684. https://doi.org/10.1080/87559129.2019.1600539

Feng JY, Zhang JC (2015) Preparation and oil/air filtration properties of hemp paper. J Ind Text 45:3-32. https://doi.org/10.1177/15280 83714521071

Fernandez-Ruiz J, Sagredo O, Pazos MR, Garcia C, Pertwee R, Mechoulam R, Martinez-Orgado J (2013) Cannabidiol for neurodegenerative disorders: Important new clinical applications for this phytocannabinoid? Br J Clin Pharmacol 75:323-333. https://doi. org/10.1111/j.1365-2125.2012.04341.x

Fernando AL, Duarte MP, Vatsanidou A, Alexopoulou E (2015) Environmental aspects of fiber crops cultivation and use. Ind Crops Prod 68:105-115. https://doi.org/10.1016/j.indcrop.2014.10.003

Fernea R, Manea DL, Tamas-Gavrea DR, Miron OI (2017) Preliminary research on using industrial plants in constructions. Sci Pap Ser Manag Econ Eng Agric Rural Dev 17:203-208

Figueiredo JA, Ismael MI, Anjo CMS, Duarte AP (2010) Cellulose and derivatives from wood and fibers as renewable sources of raw materials. Top Curr Chem 294:117-128

Fike J (2016) Industrial hemp: renewed opportunities for an ancient crop. Crit Rev Plant Sci 35:406-424. https://doi. org/10.1080/07352689.2016.1257842

Finnan J, Styles D (2013) Hemp: a more sustainable annual energy crop for climate and energy policy. Energy Policy 58:152-162. https ://doi.org/10.1016/j.enpol.2013.02.046

Fiorini D, Molle A, Nabissi M, Santini G, Benelli G, Maggi F (2019) Valorizing industrial hemp (Cannabis sativa L.) by-products: cannabidiol enrichment in the inflorescence essential oil optimizing sample pretreatment prior to distillation. Ind Crops Prod 128:581-589. https://doi.org/10.1016/j.indcrop.2018.10.045

Frassinetti S, Moccia E, Caltavuturo L, Gabriele M, Longo V, Bellani L, Giorgi G, Giorgetti L (2018) Nutraceutical potential of hemp (Cannabis sativa L.) seeds and sprouts. Food Chem 262:56-66. https://doi.org/10.1016/j.foodchem.2018.04.078

Gallos A, Paës G, Allais F, Beaugrand J (2017) Lignocellulosic fibers: a critical review of the extrusion process for enhancement of the properties of natural fiber composites. RSC Adv 7:34638. https ://doi.org/10.1039/c7ra05240e

Gedik G, Avinc O (2018) Bleaching of hemp (Cannabis sativa L.) fibers with peracetic acid for textiles industry purposes. Fibers Polym 19:82-93. https://doi.org/10.1007/s12221-018-7165-0

George M, Chae M, Bressler DC (2016) Composite materials with bast fibres: structural, technical, and environmental properties. Prog Mater Sci 83:1-23. https://doi.org/10.1016/j.pmats ci.2016.04.002

Gholampour A, Ozbakkaloglu T (2020) A review of natural fiber composites: properties, modification and processing techniques, characterization, applications. J Mater Sci 55:829-892. https://doi. org/10.1007/s10853-019-03990-y

Gibson K (2006) Hemp in the British Isles. J Ind Hemp 11:57-67

Girgih AT, Alashi A, He R, Malomo S, Aluko RE (2014a) Preventive and treatment effects of a hemp seed (Cannabis sativa L.) meal protein hydrolysate against high blood pressure in spontaneously hypertensive rats. Eur J Nutr 53:1237-1246

Girgih AT, Alashi AM, He R, Malomo SA, Raj P, Netticadan T, Aluko RE (2014b) A novel hemp seed meal protein hydrolysate reduces oxidative stress factors in spontaneously hypertensive rats. Nutrients 6:5652-5666

Girgih AT, He R, Malomo S, Offengenden M, Wu J, Aluko RE (2014c) Structural and functional characterization of hemp (Cannabis sativa L.) protein-derived antioxidant and antihypertensive peptides. J Funct Foods 6:384-394. https://doi.org/10.1016/j. jff.2013.11.005 
Gomes HI (2012) Phytoremediation for bioenergy: challenges and opportunities. Environ Technol Rev 1:59-66. https://doi. org/10.1080/09593330.2012.696715

Górski R, Szklarz M, Kaniewski R (2009) Efficacy of hemp essential oil in the control of rosy apple aphid (Dysaphis plantaginea Pass.) occurring on apple tree. Prog Plant Prot 49:2013-2016

Gourlay E, Gle P, Marceau S, Foy C, Moscardelli S (2017) Effect of water content on the acoustical and thermal properties of hemp concretes. Constr Build Mater 139:513-523. https://doi. org/10.1016/j.conbuildmat.2016.11.018

Gupta AK, Verma SK, Khan K, Verma RK (2013) Phytoremediation using aromatic plants: a sustainable approach for remediation of heavy metal polluted sites. Environ Sci Technol 47:1011510116. https://doi.org/10.1021/es403469c

Hadnađev M, Dapčević-Hadnađev T, Lazaridou A, Moschakis T, Michaelidou AM, Popović S, Biliaderis CG (2018) Hempseed meal protein isolates prepared by different isolation techniques. Part I. Physicochemical properties. Food Hydrocoll 79:526-533. https://doi.org/10.1016/j.foodhyd.2017.12.015

Hanus LO (2009) Pharmacological and therapeutics secrets of plant and brain (endo) cannabinoids. Med Res Rev 29:213-271

Harris AT, Riddlestone S, Bell Z, Hatwell PR (2008) Towards zero emission pulp and paper production: the bioregional minimill. J Clean Prod 16:1971-1979. https://doi.org/10.1016/j.jclep ro.2008.02.005

Hartsel JA, Eades J, Hickory B, Makriyannis A (2016) Cannabis sativa and hemp. In: Gupta RC (ed) Nutraceuticals-efficacy, safety and toxicity. Elsevier, Amsterdam, pp 735-754. https://doi. org/10.1016/B978-0-12-802147-7.00053-X

Holler JM, Bosy TZ, Dunkley CS, Levine B, Past MR, Jacobs A (2008) $\Delta$ 9-Tetrahydrocannabinol content of commercially available hemp products. J Anal Toxicol 32:428-432

Ingrao C, Lo Giudice A, Bacenetti J, Tricase C, Dotelli G, Fiala M, Siracusa V, Mbohwa C (2015) Energy and environmental assessment of industrial hemp for building applications: a review. Renew Sustain Energy Rev 51:29-42. https://doi.org/10.1016/j. rser.2015.06.002

Ionescu N, Popescu M, Bratu A, Istrati D, Ott C, Meghea A (2015) Valuable Romanian vegetable oils and extracts with high pharmaco-cosmetic potential. Rev Chim 66:1267-1272

Ip K, Miller A (2012) Life cycle greenhouse gas emissions of hemplime wall constructions in the UK. Resour Conserv Recycl 69:19. https://doi.org/10.1016/j.resconrec.2012.09.001

Isman MB (2015) A renaissance for botanical insecticides? Pest Manag Sci 71:1587-1590. https://doi.org/10.1002/ps.4088

Jami T, Rawtani D, Agrawal YK (2016) Hemp concrete: carbonnegative construction. Emerg Mater Res 5:1-7. https://doi. org/10.1680/jemmr.16.00122

Jami T, Karade SR, Singh LP (2019) A review of the properties of hemp concrete for green building applications. J Clean Prod 239:117852. https://doi.org/10.1016/j.jclepro.2019.117852

Jeske S, Zannini E, Arendt EK (2018) Past, present and future: the strength of plant-based dairy substitutes based on gluten-free raw materials. Food Res Int 110:42-51. https://doi.org/10.1016/j. foodres.2017.03.045

Jiang Y, Lawrence M, Ansell MP, Hussain A (2018) Cell wall microstructure, pore size distribution and absolute density of hemp shiv. R Soc Open Sci 5:171945. https://doi.org/10.1098/ rsos. 171945

Johnson P (1999) A critical review of claimed potentials for Cannabis sativa. Tappi J 82:113-123

Johnson R (2018) Hemp as an agricultural commodity. Congressional Research Service 7-5700, pp 1-48. www.crs.gov

Jonaitiene V, Jankauskiene Z, Stuoge I (2016) Hemp cultivation opportunities and perspectives in Lithuania. In: Fangueiro R, Rana S (eds) Natural fibers: advances in science and technology toward industrial applications. From science to market. Springer, Berlin, pp 407-415. https://doi.org/10.1007/978-94-017-7515-1

Jørgensen CE, Abrahamsen RK, Rukke EO, Hoffmann TK, Johansen AG, Skeie SB (2019) Processing of high-protein yoghurt-a review. Int Dairy J 88:42-59. https://doi.org/10.1016/j.dairy 1.2018.08.002

Kallakas H, Narep M, Narep A, Poltimae T, Kers J (2018) Mechanical and physical properties of industrial hemp-based insulation materials. Proc Estonian Acad Sci 67:183-192. https://doi. org/10.3176/proc.2018.2.10

Karaduman Y, Ozdemir H, Karaduman NS, Ozdemir G (2018) Interfacial modification of hemp fiber-reinforced composites. IntechOpen 2:17-39. https://doi.org/10.5772/intechopen.70519

Karche T, Singh RM (2019) The application of hemp (Cannabis sativa L.) for a green economy: a review. Turk J Bot 43:710-723. https ://doi.org/10.3906/bot-1907-15

Karus M, Vogt D (2004) European hemp industry: cultivation, processing and product lines. Euphytica 140:7-12. https://doi. org/10.1007/s10681-004-4810-7

Khattab MM, Dahman Y (2019) Production and recovery of poly-3-hydrobutyrate bioplastics using agro-industrial residues of hemp hurd biomass. Bioprocess Biosyst Eng. https://doi.org/10.1007/ s00449-019-02109-6

King JW (2019) The relationship between cannabis/hemp use in foods and processing methodology. Curr Opin Food Sci 28:32-40. https://doi.org/10.1016/j.cofs.2019.04.007

Kinnane O, Reilly A, Grimes J, Pavia S, Walker R (2016) Acoustic absorption of hemp-lime construction. Constr Build Mater 122:674-682. https://doi.org/10.1016/j.conbuildmat.2016.06.106

Kiruthika AV (2017) A review on physico-mechanical properties of bast fibre reinforced polymer composites. J Build Eng 9:91-99. https://doi.org/10.1016/j.jobe.2016.12.003

Kolodziejczyk P, Ozimek L, Kozlowska J (2012) The application of flax and hemp seeds in food, animal feed and cosmetics production. In: Kozlowski RM (ed) Handbook of natural fibres, vol 2. Elsevier, Amsterdam, pp 329-366. https://doi.org/10.1016/B9781-84569-698-6.50011-5

Korus J, Witczak M, Ziobro R, Juszczak L (2017) Hemp (Cannabis sativa subsp. sativa) flour and protein preparation as natural nutrients and structure forming agents in starch based glutenfree bread. Lebensm Wiss Technol 84:143-150. https://doi. org/10.1016/j.lwt.2017.05.046

Kostić MM, Skundric PD, Milosavljevic S (2003) Hemp is coming back (in Serbia). Tekstilna Ind 51:9-16

Kostić MM, Pejić BM, Skundric PD (2008) Quality of chemically modified hemp fibres. Bioresour Technol 99:94-99. https://doi. org/10.1016/j.biortech.2006.11.050

Kostić MM, Pejić BM, Asanovic KA, Aleksic VM, Skundric PD (2010) Effect of hemicelluloses and lignin on the sorption and electric properties of hemp fibres. Ind Crops Prod 32:169-174. https://doi.org/10.1016/j.indcrop.2010.04.014

Kostić M, Vukčević M, Pejić B, Kalijadis A (2014) Hemp fibers: old fibers - new applications. In: Ibrahim MD, Mondal M (eds) Textiles: history, properties and performance and applications. Nova Science Publishers Inc, New York, pp 399-446

Kostić M, Pejić B, Vukčević M (2018) Waste hemp (Cannabis sativa) fibers as a biosorbent and a precursor for biocarbon sorbents: influence of their chemical composition on $\mathrm{Pb}$ (II) removal. In: Stevanovic T (ed) Chemistry of lignocellulosics: current trends. CRC Press, Boca Raton, pp 3-21. https://doi.org/10.1201/b20936

Kozlowski R, Baraniecki P, Barriga-Bedoya J (2005) Bast fibres (flax, hemp, jute, ramie, kenaf, abaca). In: Blackburn RS (ed) Biodegradable and sustainable fibres. CRC Press, Cambridge, pp 36-88. https://doi.org/10.1533/9781845690991.36

Kreuger E, Sipos B, Zacchi G, Svensson SE, Björnsson L (2011) Bioconversion of industrial hemp to ethanol and methane: 
the benefits of steam pretreatment and co-production. Bioresour Technol 102:3457-3465. https://doi.org/10.1016/j.biort ech.2010.10.126

Kuglarz M, Gunnarsson IB, Svensson SE, Prade T, Johansson E, Angelidaki I (2014) Ethanol production from industrial hemp: effect of combined dilute acid/steam pretreatment and economic aspects. Bioresour Technol 163:236-243. https://doi. org/10.1016/j.biortech.2014.04.049

Kuglarz M, Alvarado-Morales M, Karakashev D, Angelidaki I (2016) Integrated production of cellulosic bioethanol and succinic acid from industrial hemp in a biorefinery concept. Bioresour Technol 200:639-647. https://doi.org/10.1016/j. biortech.2015.10.081

Kumar R, Ul Haq MI, Raina A, Anand A (2019) Industrial applications of natural fibre-reinforced polymer composites - challenges and opportunities. Int J Sustain Eng 12:212-220. https://doi. org/10.1080/19397038.2018.1538267

Kyzas GZ, Terzopoulou Z, Nikolaidis V, Alexopoulou E, Bikiaris DN (2015) Low-cost hemp biomaterials for nickel ions removal from aqueous solutions. J Mol Liq 209:209-218. https://doi. org/10.1016/j.molliq.2015.05.060

Lamberti DD, Sarkar AK (2017) Hemp fiber for furnishing applications. In: 17th World textile conference AUTEX 2017. IOP Publishing, Mat Sci Eng 254:192009. https://doi.org/10.1088/1757899X/254/19/192009

Latif E, Lawrence M, Shea A, Walker P (2015) Moisture buffer potential of experimental wall assemblies incorporating formulated hemp-lime. Build Environ 93:199-209. https://doi.org/10.1016/j. buildenv.2015.07.011

Leonard W, Zhang PZ, Ying DY, Fang ZX (2020) Hempseed in food industry: nutritional value, health benefits, and industrial applications. Compr Rev Food Sci Food Saf 19:282-308. https://doi. org/10.1111/1541-4337.12517

Leson G (2013) Hemp seeds for nutrition. In: Bouloc P, Allegret S, Arandu L (eds) hemp-industrial production and uses. CABI, Wallingford, pp 229-238

Li SY, Stuart JD, Li Y, Parnas RS (2010) The feasibility of converting Cannabis sativa L. oil into biodiesel. Bioresour Technol 101:8457-8460. https://doi.org/10.1016/j.biortech.2010.05.064

Liberalato D (2003) Prospect of hemp utilization in the European textile industry. Agroindustria 2(3):147-148

Ligeza M, Wygladacz D, Tobiasz A, Jaworecka K, Reich A (2016) Natural cold pressed oils as cosmetic products. Family Med Primary Care Rev 18:443-447. https://doi.org/10.5114/fmpcr.2016.63699

Linger P, Müssig J, Fischer H, Kobert J (2002) Industrial hemp (Cannabis sativa $\mathrm{L}$.) growing on heavy metal contaminated soil: fibre quality and phytoremediation potential. Ind Crops Prod 16:33-42

Liu M, Thygesen A, Summerscales J, Meyer AS (2017) Targeted pretreatment of hemp bast fibres for optimal performance in biocomposites materials: a review. Ind Crops Prod 108:660-683. https ://doi.org/10.1016/j.indcrop.2017.07.027

Liuzzi S, Sanarica S, Stefanizzi P (2017) Use of agro-wastes in building materials in the Mediterranean area: a review. Energy Procedia 126:242-249

Loiacono S, Morin-Crini N, Cosentino C, Torri G, Chanet G, Winterton P, Crini G (2017a) Simultaneous removal of $\mathrm{Cd} \mathrm{Co,} \mathrm{Cu,}$ $\mathrm{Mn}, \mathrm{Ni}$ and $\mathrm{Zn}$ from synthetic solutions on a hemp-based felt: experimental design. J Appl Polym Sci 134:1-11. https://doi. org/10.1002/app.44422

Loiacono S, Crini G, Martel B, Chanet G, Cosentino C, Raschetti M, Placet V, Torri G, Morin-Crini N (2017b) Simultaneous removal of $\mathrm{Cd} \mathrm{Co}, \mathrm{Cu}, \mathrm{Mn}, \mathrm{Ni}$ and $\mathrm{Zn}$ from synthetic solutions on a hemp-based felt. 2: chemical modification. J Appl Polym Sci 134:1-16. https://doi.org/10.1002/app.45138

Loiacono S, Morin-Crini G, Cosentino C, Chanet G, Winterton P, Torri G, Crini G (2017c) La canapa: un material interessante per il trattamento delle acque contaminate da metalli. Chim Ind 2:8-12. https://doi.org/10.17374/CI.2017.99.2

Loiacono S, Morin-Crini N, Martel B, Chanet G, Bradu C, Torri G, Crini G (2018a) Zinc, copper, and manganese complexation by hemp: chemical abatement and ecotoxicological impact. Environ Risque Santé 17:240-252. https://doi.org/10.1684/ers.2018.1174

Loiacono S, Crini G, Chanet G, Raschetti M, Placet V, Morin-Crini N (2018b) Metals in aqueous solutions and real effluents: biosorption behavior of a hemp-based felt. J Chem Technol Biotechnol. https://doi.org/10.1002/jctb.5612

Lu X, Clarke RC (1995) The cultivation and use of hemp (Cannabis sativa L.) in ancient China. J Int Hemp Assoc 2:26-32

Lupul I, Yperman J, Carleer R, Gryglewicz G (2015a) Adsorption of atrazine on hemp stem-based activated carbons with different surface chemistry. Adsorpt J Int Adsorpt Soc 21:489-498. https ://doi.org/10.1007/s 10450-015-9689-1

Lupul I, Yperman J, Carleer R, Gryglewicz G (2015b) Tailoring of porous texture of hemp stem-based activated carbon produced by phosphoric acid activation in steam atmosphere. J Porous Mater 22:283-289. https://doi.org/10.1007/s10934-014-9894-4

Malomo SA, Aluko RE (2015a) A comparative study of the structural and functional properties of isolated hemp seed (Cannabis sativa L.) albumin and globulin fractions. Food Hydrocoll 43:743-752. https://doi.org/10.1016/j.foodhyd.2014.08.001

Malomo SA, Aluko RE (2015b) Conversion of a low protein hemp seed meal into a functional protein concentrate through enzymatic digestion of fibre coupled with membrane ultrafiltration. Innov Food Sci Emerg Technol 31:151-159. https://doi.org/10.1016/j. ifset.2015.08.004

Malomo SA, He R, Aluko RE (2014) Structural and functional properties of hemp seed protein products. J Food Sci 79(8):C1512C1521. https://doi.org/10.1111/1750-3841.12537

Mamone G, Picariello G, Ramondo A, Nicolai MA, Ferranti P (2019) Production, digestibility and allergenicity of hemp (Cannabis sativa L.). Food Res Int 115:562-571. https://doi.org/10.1016/j. foodres.2018.09.017

Manaia JP, Manaia AT, Rodriges L (2019) Industrial hemp fibers: an overview. Fibers 7:106. https://doi.org/10.3390/fib7120106

Manosroi A, Chankhampan C, Kietthanakorn BO, Ruksiriwanich W, Chaikul P, Boonpisuttinant K, Sainakham M, Manosroi W, Tangjai T, Manosroi J (2019) Pharmaceutical and cosmeceutical biological activities of hemp (Cannabis sativa $\mathrm{L}$ var. sativa) leaf and seed extracts. Chiang Mai J Sci 46:180-195

Mazhoud B, Collet F, Pretot S, Lanos C (2017) Mechanical properties of hemp-clay and hemp stabilized clay composites. Constr Build Mater 155:1126-1137. https://doi.org/10.1016/j.conbu ildmat.2017.08.121

Miao C, Hui LF, Liu Z, Tang X (2014) Evaluation of hemp root bast as a new material for papermaking. BioResources 9:132-142

Mikulcová V, Kašpárková V, Humpoliček P, Buňková L (2017) Formulation, characterization and properties of hemp seed oil and its emulsions. Molecules 22:700. https://doi.org/10.3390/molec ules22050700

Mikulec A, Kowalski S, Sabat R, Skoczylas L, Tabaszewska M, Wywrocka-Gurgul A (2019) Hemp flour as a valuable component for enriching physicochemical and antioxidant properties of wheat bread. LWT Food Sci Technol 102:64-172. https://doi. org/10.1016/j.lwt.2018.12.028

Milanovic J, Kostić M, Milanovic P, Skundric P (2012) Influence of TEMPO-mediated oxidation on properties of hemp fibres. Ind Eng Chem Res 51:9750-9759. https://doi.org/10.1021/ie300713x

Miller SA (2018) Natural fiber textile reinforced bio-based composites: mechanical properties, creep, and environmental impacts. J Clean Prod 198:612-623. https://doi.org/10.1016/j.jclepro.2018.07.038

Mirski R, Boruszewski P, Trociński A, Dziurka D (2017) The possibility to use long fibres from fast growing hemp (Cannavis sativa 
L.) for the production of boards for the building and furniture industry. BioResources 12:3521-3529. https://doi.org/10.1016/j. indcrop.2017.07.027

Morin-Crini N, Loiacono S, Placet V, Torri G, Bradu C, Kostić M, Cosentino C, Chanet G, Martel B, Lichtfouse E, Crini G (2018) Hemp-based materials for metal removal. In: Crini G, Lichtfouse E (eds) Green adsorbents for pollutant removal, vol 19. Springer, Cham, pp 1-34. https://doi.org/10.1007/978-3-319-92162-4_1

Morin-Crini N, Loiacono S, Placet V, Torri G, Bradu C, Kostić M, Cosentino C, Chanet G, Martel B, Lichtfouse É, Crini G (2019) Hemp-based adsorbents for sequestration of metals: a review. Environ Chem Lett. https://doi.org/10.1007/s10311-018-0812-x

Moujalled B, Ait Ouméziane Y, Moissette S, Bart M, Lanos C, Samri D (2018) Experimental and numerical evaluation of the hygrothermal performance of a hemp lime concrete building: a long term case study. Build Environ 136:11-27. https://doi.org/10.1016/j. buildenv.2018.03.025

Mukhtar T, Kayani MZ, Hussain MA (2013) Nematicidal activities of Cannabis sativa L. and Zanthoxylum alatum Roxb. against Meloidogyne incognita. Ind Crops Prod 42:447-453. https://doi. org/10.1016/j.indcrop.2012.06.027

Musio S, Müssig J, Amaducci S (2018) Optimizing hemp fiber production for high performance composite applications. Front Plant Sci 9:1702. https://doi.org/10.3389/fpls.2018.01702

Müssig J (2010) Industrial applications of natural fibres. Structure, properties and technical applications. Willey, Chichester. ISBN 978-0-470-69501-1

Niyigena C, Amziane S, Chateauneuf A, Arnaud L, Bessette L, Collet F, Lanos C, Escadeillas G, Lawrence M, Magniont C, Marceau S, Pavia S, Peter U, Picandet V, Sonebi M, Walker P (2016) Variability of mechanical properties of hemp concrete. Mater Today Commun 7:122-133. https://doi.org/10.1016/j.mtcom m.2016.03.003

Nováková P (2018) Use of technical hemp in the construction industry. MATEC Web of Conf 146:03011. https://doi.org/10.1051/matec conf/201814603011

Nunes L (2017) Nonwood bio-based materials. In: Jones D, Brischke $\mathrm{C}$ (eds) Performance of bio-based building materials. Elsevier, Amsterdam, pp 97-186. https://doi.org/10.1016/B978-0-08100982-6.00003-3

Nurazzi NM, Khalina A, Sapuan SM, Laila AHAMD, Rahmah M, Hanafee Z (2017) A review: fibres, polymer matrices and composites. Pertanika J Sci Technol 25:1085-1102

Pacaphol K, Aht-Ong D (2017) Preparation of hemp nanofibers from agricultural waste by mechanical defibrillation in water. J Clean Prod 142:1283-1295. https://doi.org/10.1016/j.jclep ro.2016.09.008

Parian A, Limketkai BN (2016) Dietary supplement therapies for inflammatory bowel disease: Crohn's disease and ulcerative colitis. Curr Pharm Des 22:180-188

Pathak T, Kaur J, Kumar R, Kuldeep K (2016) Development of electrochemical biosensor for detection of asparagine in leukemic samples. Int J Pharm Sci Res 7:783-788

Pavela R, Benelli G (2016) Essential oils as ecofriendly biopesticides? Challenges and constraints. Trends Plant Sci 21:1000-1007. https://doi.org/10.1016/j.tplants.2016.10.005

Pejić BM, Kostić MM, Skundric PD, Praskalo JZ (2008) The effects of hemicelluloses and lignin removal on water uptake behavior of hemp fibres. Bioresour Technol 99:7152-7159. https://doi. org/10.1016/j.biortech.2007.12.073

Pejić BM, Vukčević MM, Kostić MP, Skundric PD (2009) Biosorption of heavy metal ions from aqueous solutions by short hemp fibres: effect of chemical composition. J Hazard Mater 164:146-153. https://doi.org/10.1016/j.jhazmat.2008.07.139

Pejić BM, Vukčević MM, Pajić-Lijaković ID, Laušević MD, Kostić MM (2011) Mathematical modeling of heavy metal ions $\left(\mathrm{Cd}^{2+}\right.$,
$\mathrm{Zn}^{2+}$ and $\mathrm{Pb}^{2+}$ ) biosorption by chemically modified short hemp fibres. Chem Eng J 172:354-360. https://doi.org/10.1016/j. cej.2011.06.016

Pichardo PP, Martínez-Barrera G, Martínez-López M, Ureña-Núñez F, Ávila-Córdoba LI (2018) Waste and recycled textiles as reinforcements of building materials. IntechOpen 6:89-105. https:// doi.org/10.5772/intechopen.70620

Pihlanto A, Mattila P, Mäkinen S, Pajari AM (2017) Bioactivities of alternative protein sources and their potential health benefits. Food Funct 8:3443-3458. https://doi.org/10.1039/C7FO00302A

Pil L, Bensadoun F, Pariset J, Verpoest I (2016) Why are designers fascinated by flax and hemp fibres composites? Compos Part A 83:193-205. https://doi.org/10.1016/j.compositesa.2015.11.004

Pittau F, Krause F, Lumia G, Habert G (2018) Fast-growing bio-based materials as an opportunity for storing carbon in exterior walls. Build Environ 129:117-129. https://doi.org/10.1016/j.build env.2017.12.006

Prade T, Svensson SE, Andersson A, Mattsson JE (2011) Biomass and energy yield of industrial hemp grown for biogas and solid fuel. Biomass Bioenergy 35:3040-3049. https://doi.org/10.1016/j. biombioe.2011.04.006

Prade T, Svensson SE, Mattsson JE (2012) Energy balances for biogas and solid biofuel production from industrial hemp. Biomass Bioenergy 40:36-52. https://doi.org/10.1016/j.biomb ioe.2012.01.045

Pretot S, Collet F, Garnier C (2014) Life cycle assessment of a hemp concrete wall: impact of thickness and coating. Build Environ 72:223-231. https://doi.org/10.1016/j.buildenv.2013.11.010

Przybysz Buzala K, Kalinowska H, Przybysz P, Malachowska E (2017) Conversion of various types of lignocellulosic biomass to fermentable sugars using kraft pulping and enzymatic hydrolysis. Wood Sci Technol 51:873-885. https://doi.org/10.1007/s0022 6-017-0916-7

Ranalli P (1999) Advances in hemp research. Food Product Press, Binghamton, p 272. ISBN 978-1-560-22872-1

Ranalli P, Venturi G (2004) Hemp as a raw material for industrial applications. Euphytica 140:1-6. https://doi.org/10.1007/s1068 1-004-4749-8

Rehman MSU, Rashid N, Saif A, Mahmood T, Han JI (2013) Potential of bioenergy production from industrial hemp (Cannabis sativa): Pakistan perspective. Renew Sustain Energy Rev 18:154-164. https://doi.org/10.1016/j.rser.2012.10.019

Rezić I (2013) Cellulosic fibres-biosorptive materials and indicators of heavy metal pollution. Microchem J 107:63-69

Rice B (2008) Hemp as feedstock for biomass-to-energy conversion. J Ind Hemp 13:145-156. https://doi.org/10.1080/1537788080 2391274

Richard D, Dejean C (2013) Medicinal uses of hemp. In: Bouloc P (ed) Hemp-industrial production and uses. CABI International, Wallingford, pp 222-228. ISBN 978-1-84593-793-5

Rijavec T, Janjić S, Ačko DK (2017) Revitalization of industrial hemp Cannabis sativa L. var. sativa in Slovenia: a study of green hemp fibres. Tekstilec 60:36-48. https://doi.org/10.14502/Tekstilec2 017.60.36-48

Robinson R (1996) The great book of hemp. The complete guide to the environmental, commercial and medicinal uses of the world's most extraordinary plant. Park Street Press, Rochester. ISBN 978-0-892-81541-8

Rodriguez-Leyva D, Pierce GN (2010) The cardiac and haemostatic effects of dietary hempseed. Nutr Metab 7:32-40

Rosas JM, Bedia J, Rodriguez-Mirasol J, Cordero T (2009) Hempderived activated carbon fibres by chemical activation with phosphoric acid. Fuel 88:19-26. https://doi.org/10.1016/j. fuel.2008.08.004

Rossi E, Di Nicolantonio M, Barcarolo P, Lagatta J (2020) Sustainable 3D printing: design opportunities and research 
perspectives. Adv Intell Syst Comput 975:3-15. https://doi. org/10.1007/978-3-030-20216-3_1

Roulac JW (1997) Hemp horizons: the comeback of the world's most promising plant, 1st edn. The real goods solar living book. Chelsea Green Pub Co, Vermont, p 226. ISBN 978-0-930-03193-0

Russo EB (2007) History of cannabis and its preparations in saga, science and sobriquet. Chem Biodivers 4:1614-1648

Russo R, Reggiani R (2013) Variability in antinutritional compounds in hempseed meal of Italian and French varieties. Plant 1:25-29. https://doi.org/10.11648/j.plant.201301102.13

Sadrmanesh V, Chen Y (2019) Bast fibres: structure, processing, properties and applications. Int Mater Rev 64:381-406. https://doi. org/10.1080/09506608.2018.1501171

Salentijn EMJ, Zhang Q, Amaducci S, Yang M, Trindade LM (2015) New developments in fiber hemp (Cannabis sativa L.) breeding. Ind Crops Prod 68:32-41. https://doi.org/10.1016/j.inder op.2014.08.011

Salentijn EMJ, Petit J, Trindade LM (2019) The complex interactions between flowering behavior and fiber quality in hemp. Front Plant Sci 10:164. https://doi.org/10.3389/fpls.2019.00614

Sarasini F, Fiore V (2018) A systematic literature review on less common natural fibres and their biocomposites. J Clean Prod 195:240-267. https://doi.org/10.1016/j.jclepro.2018.05.197

Sawler J, Stout JM, Gardner KM, Hudson D, Vidmar J, Butler L, Page JE, Myles S (2015) The genetic structure of marijuana and hemp. PLoS ONE 10:e133292. https://doi.org/10.1371/journ al.pone. 0133292

Saxena G, Purchase D, Mulla SI, Saratale GD, Bharagava RN (2020) Phytoremediation of heavy metal-contaminated sites: ecoenvironmental concerns, field studies, sustainability issues, and future prospects. Rev Environ Contam Toxicol 249:71-131. https ://doi.org/10.1007/398_2019_24

Schluttenhofer C, Yuan L (2017) Challenges towards revitalizing hemp: a multifaced crop. Trends Plant Sci 22:917-929. https:// doi.org/10.1016/j.tplants.2017.08.004

Schultes RE (1970) Random thoughts and queries on the botany of Cannabis. In: Joyce RB, Curry SH (eds) The botany and chemistry of Cannabis. J\&A Churchill, London, pp 11-34. ISBN 0-700-01479-9

Sepe R, Bollino F, Boccarusso L, Caputo F (2018) Influence of chemical treatments on mechanical properties of hemp fiber reinforced composites. Compos Part B 133:210-217. https://doi. org/10.1016/j.compositesb.2017.09.030

Shahzad A (2012) Hemp fiber and its composites-a review. J Compos Mater 46:973-986. https://doi.org/10.1177/002199831143623

Sipos B, Kreuger E, Svensson SE, Réczey K, Björnsoon L, Zacchi G (2010) Steam pretreatment of dry and ensiled industrial hemp for ethanol production. Biomass Bioenergy 34:1721-1731. https:// doi.org/10.1016/j.biombioe.2010.07.003

Small E, Marcus D (2002) Hemp: a new crop with new uses for North America. In: Janick J, Whipkey A (eds) Trends in new crops and new uses. ASHS Press, Alexandria, pp 284-326

Spierling S, Knüpffer E, Behnsen H, Muderbasch M, Krieg H, Springer S, Albrecht S, Herrmann C, Endres HJ (2018) Biobased plastics - a review of environmental, social and economic impact assessments. J Clean Prod 185:476-491. https://doi. org/10.1016/j.jclepro.2018.03.014

Sponner J, Toth L, Cziger S, Franck RE (2005) Hemp. In: Franck RE (ed) Bast and other plant fibres. Woodhead publishing series in textiles. Elsevier, Amsterdam, pp 176-206. https://doi. org/10.1533/9781845690618.176

Stevulova N, Cigasova J, Estokova A, Terpakova E, Geffert A, Kacik F, Singovszka E, Holub M (2014) Properties and characterization of chemically modified hemp hurds. Materials 7:8131-8150. https ://doi.org/10.3390/ma7128131
Sun JJ, Gao JM, Hao XM, Cui XY, Ma T, Yang Y (2013) Effects of air-phosphoric acid activation on pore structure and adsorption property of mesoporous carbon from hemp stem. Book Ser Adv Mater Res 821-822:41-46. https://doi.org/10.4028/www.scien tific.net/AMR.821-822.41

Sun W, Lipka SM, Swartz C, Williams D, Yang F (2016) Hempderived activated carbons for supercapacitors. Carbon 103:181192. https://doi.org/10.1016/j.carbon.2016.02.090

The SS, Birch J (2014) Effect of ultrasonic treatment on the polyphenol content and antioxidant capacity of extract from defatted hemp, flax and canola seed cakes. Ultrasonics Sonochem 21:346-353. https://doi.org/10.1016/j.ultsonch.2013.08.002

The SS, Bekhit AED, Carne A, Birch J (2016) Antioxidant and ACEinhibitory activities of hemp (Cannabis sativa $\mathrm{L}$.) protein hydrolysates produced by the proteases AFP, HT, Pro-G, actinidin and zingibain. Food Chem 203:199-206. https://doi.org/10.1016/j. foodchem.2016.02.05

Thoma TG, Sharma SK, Prakash A, Sharma BR (2000) Insecticidal properties of essential oil of Cannabis sativa Linn. against mosquito larvae. Entomonology 25:21-24

Thomas S, Paul SA, Pothan LA, Deepa B (2011) Natural fibres: structure, properties and applications. In: Kalia S, Kaith BS, Kaur I (eds) cellulose fibers: bio- and nano-polymer composites. Springer, Berlin, pp 3-42. https://doi.org/10.1007/978-3-64217370-7_1

Tofan L, Păduraru C, Volf I (2009) Concentration of cadmium (II) trace amounts from large volumes of aqueous samples of chemically modified hemp fibres. Sci Pap J Agron Ser 52:506-511

Tofan L, Păduraru C, Volf I (2010a) Comparative study concerning the retention thermodynamics of some heavy metal ions on hemp fibres. Bul Inst Politech Iasi LVI(LX):137-145

Tofan L, Păduraru C, Volf I, Balan C (2010b) Kinetic and thermodynamic profile of $\mathrm{Pb}(\mathrm{II})$ sorption by untreated hemp fibres. Sci Pap J Agron Ser 53:146-150

Tofan L, Păduraru C, Volf I, Balan C (2010c) Removal of lead(II) from aqueous solution by sorption by on natural hemp fibres. Sci Pap J Agron Ser 53:150-153

Tofan L, Teodosiu C, Păduraru C, Wenkert R (2013) Cobalt(II) removal from aqueous solutions by natural hemp fibres: batch and fixed-bed columns studies. Appl Surf Sci 285:33-39. https ://doi.org/10.1016/j.apsusc.2013.06.151

Tofan L, Păduraru C, Teodosiu C, Toma O (2015) Fixed bed columns study on the removal of chromium(III) ions from aqueous solutions by hemp fibres with improved sorption performance. Cellul Chem Technol 49:219-229

Tofan L, Păduraru C, Toma O (2016a) Zinc remediation of aqueous solutions by natural hemp fibres: batch desorption/regeneration study. Des Water Treat 57:12644-12652. https://doi. org/10.1080/19443994.2015.1052566

Tofan L, Wenkert R, Păduraru C (2016b) Natural and waste materials as green sorbents for $\mathrm{Cd}(\mathrm{II})$ removal from aqueous effluents. Environ Eng Manag J 15:1049-1058

Ummartyotin S, Pechyen C (2016) Strategies for development and implementation of bio-based materials as effective renewable resources of energy: a comprehensive review on adsorbent technology. Renew Sustain Energy Rev 62:654-664. https://doi. org/10.1016/j.rser.2016.04.066

Usmani MA, Anas M (2018) Study of natural fibre reinforced composites. In: 1st International conference contemporary res mechanical engineering ICCRME-2018. Book series: IOP conference series materials science and engineering vol 404, pp 012048. https://doi.org/10.1088/1757-899X/404/1/012048

Väisänen T, Batello P, Lappalainen R, Tomppo L (2018) Modification of hemp fibers (Cannabis sativa L.) for composite applications. Ind Crops Prod 111:422-429. https://doi.org/10.1016/j.inder op.2017.10.049 
Vandenhove H, Van Hees M (2003) Fibre crops as alternative land use for radioactively contaminated arable land. J Environ Radioact 81:131-141. https://doi.org/10.1016/j.jenvrad.2005.01.002

VanDolah HJ, Bauer BA, Mauck KF (2019) Clinicians's guide to cannabidiol and hemp oils. Mayo Clinic Proc 94:1840-1851. https ://doi.org/10.1016/j.mayocp.2019.01.003

Vavilov NI (1992) Origin and geography of cultivated plants. Cambridge University Press, Cambridge, Cambridge, p 498. ISBN 978-0-521-40427-3

Verma RS, Padalia RC, Verma SK, Chauhan A, Darokar MP (2014) The essential oil of bhang (Cannabis sativa $\mathrm{L}$.) for non-narcotic applications. Curr Sci 107:645-650

Vogl CR, Mölleken H, Lissek-Wolf G, Surböck A, Kobert J (2004) Hemp (Cannabis sativa L.) as a resource for green cosmetics: yield of seed and fatty acid compositions of 20 varieties under the growing conditions of organic farming in Austria. J Ind Hem 9:51-68. https://doi.org/10.1300/J237v09n01_06

Vukčević M, Kalijadis A, Radisic M, Pejić B, Kostić M, Laušević Z, Laušević M (2012) Application of carbonized hemp fibres as a new solid-phase extraction sorbent for analysis of pesticides in water samples. Chem Eng J 211:224-232. https://doi. org/10.1016/j.cej.2012.09.059

Vukčević M, Pejić B, Laušević M, Pajić-Lijaković I, Kostić M (2014a) Influence of chemically modified short hemp fiber structure on biosorption process of $\mathrm{Zn}^{2+}$ ions from waste water. Fibres Polym 15:687-697. https://doi.org/10.1007/s12221-014-0687-9

Vukčević M, Pejić B, Kalijadis A, Pajić-Lijaković I, Kostić M, Laušević Z, Laušević M (2014b) Carbon materials from waste short hemp fibres as a sorbent for heavy metal ions-mathematical modeling of sorbent structure and ions transport. Chem Eng $\mathbf{J}$ 235:284-292. https://doi.org/10.1016/j.cej.2013.09.047

Vukčević M, Kalijadis AM, Vasiljevic TM, Babic BM, Laušević ZV, Laušević MD (2015) Production of activated carbon derived from waste hemp (Cannabis sativa) fibres and its performance in pesticide adsorption. Microporous Mesoporous Mater 214:156165. https://doi.org/10.1016/j.micromeso.2015.05.012

Walker R, Pavía S (2014) Moisture transfer and thermal properties of hemp-lime concretes. Const Build Mater 64:270-276. https://doi. org/10.1016/j.conbuildmat.2014.04.081

Walker R, Pavía S, Mitchell R (2014) Mechanical properties and durability of hemp-lime concretes. Constr Build Mater 30:340-348. https://doi.org/10.1016/j.conbuildmat.2014.02.065

Wang QL, Xiong YL (2019) Processing, nutrition, and functionality of hempseed protein: a review. Compr Rev Food Sci Food Saf 18:936-952. https://doi.org/10.1111/1541-4337.12450

Wang HM, Postle R, Kessler RW, Kessler W (2003) Removing pectin and lignin during chemical processing of hemp for textile applications. Text Res J 73:664-669. https://doi.org/10.1177/00405 1750307300802

Wang Y, Yang R, Li M, Zhao ZJ (2015) Hydrothermal preparation of highly porous carbon spheres from hemp (Cannabis sativa L.) stem hemicellulose for use in energy-related applications. Ind Crops Prod 65:216-226. https://doi.org/10.1016/j.inder op.2014.12.008

Werz O, Seerges J, Shaible AM, Weinigel C, Barz D, Koeberle A, Allegrone G, Pollastro F, Zampieri L, Grassi G, Appendino G (2014) Cannaflavins from hemp sprouts, a novel cannabinoid-free hemp food product, target microsomal prostaglandin E2 synthase-1 and 5-lypoxygenase. Pharma Nutr 2:53-60. https://doi.org/10.1016/j. phanu.2014.05.001

Yang R, Liu GQ, Xu XH, Li M, Zhang JC, Hao XM (2011) Surface texture, chemistry and adsorption properties of acid blue 9 of hemp (Cannabis sativa L.) bast-based activated carbon fibres prepared by phosphoric acid activation. Biomass Bioenergy 35:437-445. https://doi.org/10.1016/j.biombioe.2010.08.061

Yang R, Liu GQ, Li M, Zhang JC, Hao XM (2012) Preparation and $\mathrm{N}_{2}$, $\mathrm{CO}_{2}$ and $\mathrm{H}_{2}$ adsorption of super activated carbon derived from biomass source hemp (Cannabis sativa L.) stem. Microporous Mesoporous Mater 158:108-116. https://doi.org/10.1016/j.micro meso.2012.03.004

Yin SW, Tang CH, Cao JS, Hu EK, Wen QB, Yang XQ (2008) Effects of limited enzymatic hydrolysis with trypsin on the functional properties of hemp (Cannabis sativa L.) protein isolate. Food Chem 106:1004-1013. https://doi.org/10.1016/j.foodc hem.2007.07.030

Yin SW, Tang CH, Wen QB, Yang XQ (2009) Functional and structural properties and in vitro digestibility of acylated hemp (Cannabis sativa L.) protein isolates. Int J Food Sci Technol 44:2653-2661. https://doi.org/10.1111/j.1365-2621.2009.02098.x

Yu Y, Zhan JB, Wan H, Zhang Y, Li LW, Yu J, Yu TT, Xie J, Yue BS (2017) Manufacturing technology and application of hemp cigarette paper with dense ash integration. In: 3rd international conference energy material environmental engineering. Book series: IOP conference series earth and environmental science 61. UNSP 012078. https://doi.org/10.1088/1755-1315/61/1/012078

Zabalza Bribián I, Valero Capilla A, Aranda Usón A (2011) Life cycle assessment of building materials: comparative analysis of energy and environmental impacts and evaluation of the eco-efficiency improvement potential. Build Environ 46:1133-1140. https://doi. org/10.1016/J.BUILDENV.2010.12.002

Zajac M, Guzik P, Kulawik P, Tkaczewska J, Florkiewicz A, Migdal W (2019) The quality of pork loaves with the addition of hemp seeds, de-hulled hemp seeds, hemp protein and hemp flour. LWT Food Sci Technol 105:190-199. https://doi.org/10.1016/j. lwt.2019.02.013

Zhang H, Zhong Z, Feng L (2016) Advances in the performance and application of hemp fiber. Int J Simul Syst Sci Technol 17:181185. https://doi.org/10.5013/IJSSST.a.17.09.18

Zhou Y, Wang S, Lou H, Fan P (2018) Chemical constituents of hemp (Cannabis sativa $\mathrm{L}$.) seed with potential anti-neuroinflammatory activity. Phytochem Lett 23:57-61. https://doi.org/10.1016/j. phytol.2017.11.013

Zou XQ, El Fallah J, Goupil JM, Zhu GS, Valtchev V, Mintova S (2012) Green removal of aromatic organic pollutants from aqueous solutions with a zeolite-hemp composite. RSC Adv 2:3115-3122. https://doi.org/10.1039/c2ra01176j

Żuk-Gołaszewska K, Gołaszewski J (2018) Cannabis sativa L.-Cultivation and quality or raw material. J Elem 23:971-984. https:// doi.org/10.5601/jelem.2017.22.3.1500 